\title{
Hydrological drought across the world: impact of climate and physical catchment structure
}

\author{
H. A. J. Van Lanen ${ }^{1}$, N. Wanders ${ }^{1,2}$, L. M. Tallaksen ${ }^{3}$, and A. F. Van Loon ${ }^{1}$ \\ ${ }^{1}$ Hydrology and Quantitative Water Management Group, Centre for Water and Climate, Wageningen University, \\ Wageningen, the Netherlands \\ ${ }^{2}$ Department of Physical Geography, Faculty of Geosciences, Utrecht University, Utrecht, the Netherlands \\ ${ }^{3}$ Department of Geosciences, University of Oslo, Oslo, Norway
}

Correspondence to: H. A. J. Van Lanen (henny.vanlanen@wur.nl)

Received: 30 September 2012 - Published in Hydrol. Earth Syst. Sci. Discuss.: 30 October 2012

Revised: 28 March 2013 - Accepted: 3 April 2013 - Published: 2 May 2013

\begin{abstract}
Large-scale hydrological drought studies have demonstrated spatial and temporal patterns in observed trends, and considerable difference exists among global hydrological models in their ability to reproduce these patterns. In this study a controlled modeling experiment has been set up to systematically explore the role of climate and physical catchment structure (soils and groundwater systems) to better understand underlying drought-generating mechanisms. Daily climate data (1958-2001) of 1495 grid cells across the world were selected that represent Köppen-Geiger major climate types. These data were fed into a conceptual hydrological model. Nine realizations of physical catchment structure were defined for each grid cell, i.e., three soils with different soil moisture supply capacity and three groundwater systems (quickly, intermediately and slowly responding). Hydrological drought characteristics (number, duration and standardized deficit volume) were identified from time series of daily discharge. Summary statistics showed that the equatorial and temperate climate types (A- and C-climates) had about twice as many drought events as the arid and polar types (B- and E-climates), and the durations of more extreme droughts were about half the length. Selected soils under permanent grassland were found to have a minor effect on hydrological drought characteristics, whereas groundwater systems had major impact. Groundwater systems strongly controlled the hydrological drought characteristics of all climate types, but particularly those of the wetter A-, C- and $D$-climates because of higher recharge. The median number of droughts for quickly responding groundwater systems was about three times higher than for slowly responding sys-
\end{abstract}

tems. Groundwater systems substantially affected the duration, particularly of the more extreme drought events. Bivariate probability distributions of drought duration and standardized deficit for combinations of Köppen-Geiger climate, soil and groundwater system showed that the responsiveness of the groundwater system is as important as climate for hydrological drought development. This urges for an improvement of subsurface modules in global hydrological models to be more useful for water resources assessments. A foreseen higher spatial resolution in large-scale models would enable a better hydrogeological parameterization and thus inclusion of lateral flow.

\section{Introduction}

Drought, desertification and other forms of water shortage are anticipated to affect as many as one-third of the world's population. Drought is one of the most extreme water-related natural hazards. On average, over 0.5 billion people in regions in China and India are annually exposed to droughts that seriously affect economic development and environment. Drought has a larger impact on poor economies than on more developed ones. For example, in western African countries, where on average over $30 \%$ of the people are exposed to drought every year, the livelihood of the people is seriously threatened (e.g., ISDR, 2009; WWDR, 2009). In 2011, a severe drought affected the entire East Africa region and contributed to a severe food crisis across Djibouti, Ethiopia, Kenya and Somalia. It threatened the livelihood of more than 
12 million people (UN, 2011). Droughts in developing countries may cause fatalities, which does not happen in prosperous countries. However, in Europe almost 80000 people died due to associated heat waves and forest fires over the period 1998-2009. Overall losses were estimated to be as high as $€ 4940$ billion over the same period (EEA, 2010). Likely, drought will worsen in many parts of the world because of climate change (e.g., Bates et al., 2008; Seneviratne et al., 2012). Moreover, vulnerability will increase in numerous regions as a response to population growth and, thus, higher demand for water. Water security and associated food supply, in particular under extreme conditions, are at stake (e.g., Falkenmark et al., 2009; WWDR, 2009; Gerten et al., 2011). Large-scale drought can also have a large impact on ecosystems. The 2010 Amazon drought showed that repeated drought may largely influence tropical forests that can shift from buffering $\mathrm{a} \mathrm{CO}_{2}$ increase into accelerating it, which can have important decadal-scale impacts on the global carbon cycle (Lewis et al., 2011).

Drought differs from other hazards in several ways. It develops slowly and usually over large areas (transnational), mostly resulting from a prolonged period (from months to years) of below-normal precipitation, and drought can occur nearly anywhere on the globe. Lack of precipitation combined with higher evaporation rates propagates through the hydrological cycle from its origin as a meteorological drought into soil moisture depletion to the point where crops or terrestrial ecosystems are impacted, and eventually into a hydrological drought (e.g., Wilhite, 2000; Tallaksen and Van Lanen, 2004; Mishra and Singh, 2010). Hydrological drought refers to a prolonged period with below-normal water availability in rivers and streams, and lakes, or groundwater bodies due to natural causes. The different types of droughts have each their own specific spatiotemporal characteristics (e.g., Peters et al., 2006; Tallaksen et al., 2009). From an impact point of view, it is important to distinguish between the different types of drought and to realize that hydrological drought indicators cannot be straightforwardly derived from meteorological drought indicators (e.g., Peters et al., 2003; Wanders et al., 2010). Understanding different types of drought, including their controlling mechanisms, is of uttermost importance for the management of water resources, where key information on hydrological drought is essential for water resources assessments.

Recently, several large-scale studies have been carried out to investigate drought at global or continental scales for present and future climate (e.g., Andreadis et al., 2005; Sheffield and Wood, 2008a, b; Shukla and Wood, 2008; Sheffield et al., 2009, 2012; Dai, 2011, 2013; Hannaford et al., 2010; Prudhomme et al., 2011; Stahl et al., 2011; Corzo Perez et al., 2011; Wehner et al., 2011; Van Huijgevoort et al., 2012). In these studies droughts were derived from time series simulated with large-scale models (e.g., general circulation models (GCMs), regional circulation models (RCMs), land surface models (LSMs), global hydrological models,
(GHMs)), usually tested against documented sources or river flow data (e.g., Döll et al., 2003; Hannah et al., 2010). Other large-scale studies have examined drought from observed data only (e.g., Hisdal et al., 2001; Peel et al., 2005; Fleig et al., 2006; Stahl et al., 2010; Wilson et al., 2010). All these studies deal with a large amount of data (gridded data or data from numerous flow gauges). However, often the necessary data on catchment properties (e.g., hydrological stores) are not available. Such data would allow an exploration of underlying drought-controlling mechanisms that could explain spatial and temporal patterns in observed or simulated data. More thorough knowledge on drought-generating mechanisms (i.e., role of climate and physical catchment structure) would support a better assessment of future drought in response to global change. So far, the role of climate and physical catchment structure as controlling mechanisms on generation of low flow or drought has only broadly been described (e.g., Smakhtin, 2001; Peters et al., 2003; Van Lanen et al., 2004a; Casado Sáenz et al., 2009; Mishra and Singh, 2010; Gudmundsson et al., 2011) or in a limited number of catchments at a detailed scale (e.g., Van Lanen and Tallaksen, 2007, 2008; LeBlanc et al., 2009; Tallaksen et al., 2009; Vidal et al., 2010; Van Loon et al., 2010, 2011; Van Loon and Van Lanen, 2012). It can be concluded from these studies that hydrological drought is affected by a complex relation between intra- and interannual climate variability and stores in the catchment (soils, groundwater, lakes). This complex relation modifies the meteorological drought as it propagates into a hydrological drought (through delaying, attenuating, lengthening, and pooling of meteorological drought events). Despite these studies, the relative importance of climate versus physical catchment structure on the development of hydrological drought still remains poorly understood.

This paper analyzes drought-controlling mechanisms at the land surface with the aim to identify the relative role of climate, and physical catchment structure (i.e., soils, aquifers) on the development of hydrological drought in a wide range of climatological settings. It adds to previous studies by performing a comprehensive and systematic analysis of hydrological drought, including the behavior of stores under various climatic regimes.

The paper starts with presenting the general design of the study and the modeling framework (i.e., the soil water balance model, groundwater model, the drought identification approach), followed by the description of how the relative role of climate and physical catchment structure is analyzed, and the data and parameters used in this study (climatic data, soils, groundwater systems) (Sect. 2). The results are presented in the form of summary statistics and probabilities of hydrological drought duration and severity for major climatic regions and a number of combinations of soil types and groundwater systems (Sect. 3). It includes an assessment of the impact of model assumptions (land use, snow accumulation and melt) on the main findings. The results are discussed in Sect. 4. Finally, the conclusions are given and 
discussed in light of the assessment of drought at the global and continental scale (Sect. 5).

\section{Methods and materials}

In this study, the relative role that climate and physical catchment structure plays on the development of hydrological drought across the world was investigated through a controlled modeling experiment. Time series of daily climate data (Sect. 2.3.1) were used as driving force for a conceptual hydrological model that combines a rather simple soil water balance model and a spatially lumped groundwater model. The model was run for a high number of randomly selected grid cells of 0.5-degree resolution across the world assuring that different climates are well represented. The role of physical catchment structure on the development of hydrological drought was explored by systematically analyzing hydrological model simulations for a series of soil type and groundwater system realizations for each grid cell. The adopted approach does not generate time series of hydrometeorological variables that are unique for a specific grid cell as large-scale models do and which are assumed to reflect reality (e.g., Haddeland et al., 2011); rather it generates a number of possible time series of hydrometeorological variables (i.e., realizations) for each grid cell. A similarity index was introduced that compares the bivariate probability distributions of hydrological drought duration and severity for different combinations of climate, soil and groundwater system. The adopted approach is an extension of an earlier method described by Van Lanen and Tallaksen $(2007,2008)$.

\subsection{Modeling framework}

Several stores (e.g., soils, groundwater) and fluxes control hydrological drought development, as presented in the conceptual diagram in Fig. 1. This diagram is a simplified representation of reality. For instance, other stores than soil moisture and groundwater storage, such as bogs and lakes, are missing. Below-normal rainfall (Pra), often in combination with higher potential evapotranspiration (ETp), causes depletion of soil moisture storage (SS), which eventually leads to negligible recharge $(\operatorname{Rch} \approx 0)$ or lower than normal Rch from the soil to the groundwater system (SG) (e.g., Van Lanen et al., 2004a). In cold regions, drought can also occur due to either lower than normal temperatures (in particular longer below zero) or higher temperatures (periods above zero that normally are frost times), which is related to snow accumulation and melt (e.g., Van Loon et al., 2011; Staudinger et al., 2011; Van Loon and Van Lanen, 2012). In a drought situation, usually there will be a below-normal recharge that feeds the groundwater system. River flow is then controlled by the groundwater storage (SG) (Fig. 1, non-shaded). Low groundwater storage at the start of the period with belownormal recharge, or a long-lasting period with below-normal

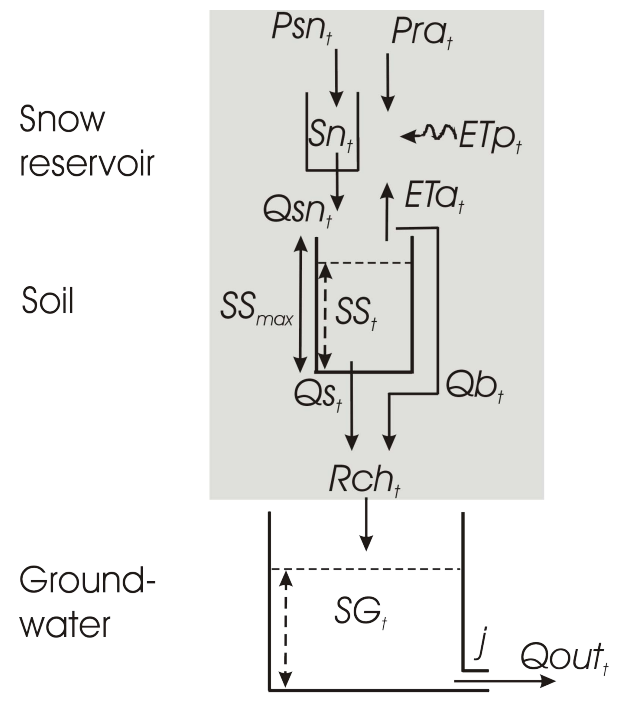

Fig. 1. Conceptual diagram of stores and fluxes controlling hydrological drought development. Psn: precipitation as snow, Pra: precipitation as rain, Sn: snow storage, ETp: potential evapotranspiration, ETa: actual evapotranspiration, Qsn: snowmelt, SS: soil water storage, $\mathrm{SS}_{\max }$ : total available soil moisture, Qs: downward flux across bottom of the soil (percolation), Qb: bypass flow, Rch: groundwater recharge, SG: groundwater storage, $j$ : groundwater response parameter, and Qout: groundwater discharge.

recharge, will cause a drought in river flow to develop (hydrological drought). A hydrological drought will end when the recharge again returns to normal (or higher than normal) for a sufficient period of time. This can be triggered by rainfall or snowmelt.

The modeling framework introduced below combines a conceptual hydrological model (i.e., a soil water balance model, including a snow module) and a simple, spatially lumped groundwater model. This modeling framework simulates stores and fluxes according to the diagram in Fig. 1.

\subsubsection{Soil water balance model}

A transient soil water balance model (shaded part of Fig. 1) that uses daily precipitation, temperature and reference evaporation as forcing data was applied to simulate time series of daily snowmelt, snow accumulation, actual evapotranspiration, soil moisture storage and groundwater recharge (Van Lanen et al., 1996). The rather simple soil water model does not simulate capillary rise. The soil may consists of up to 10 different layers to model the unsaturated zone. Land use data and soil data were used to characterize the physical catchment structure. The model solves the following daily water balance equations:

$$
\begin{aligned}
& \mathrm{SS}_{t}=\mathrm{SS}_{t-1}+\mathrm{Pra}_{t}+\mathrm{Qsn}_{t}-\mathrm{ETa}_{t}-\mathrm{Rch}_{t} \\
& \mathrm{Sn}_{t}=\mathrm{Sn}_{t-1}+\mathrm{Psn}_{t}-\mathrm{Qsn}_{t},
\end{aligned}
$$


where SS is soil water storage $(\mathrm{mm})$, Pra rainfall $\left(\mathrm{mmday}^{-1}\right)$, Qsn snowmelt $\left(\mathrm{mmday}^{-1}\right)$, ETa actual evapotranspiration $\left(\mathrm{mmday}^{-1}\right)$, Rch groundwater recharge $\left(\mathrm{mmday}^{-1}\right)$, Sn snow storage $(\mathrm{mm})$, Psn snow fall $\left(\right.$ mmday $\left.^{-1}\right)$, Qs downward flux from the soil water to the groundwater storage $\left(\mathrm{mmday}^{-1}\right), \mathrm{Qb}$ bypass flow (i.e., part of rainfall that bypasses the soil and enters the groundwater system $\left(\mathrm{mmday}^{-1}\right)$ ), and $t$ time (day).

The model uses the snow accumulation and melt approach of the well-known hydrological model HBV, as described by Seibert (2005). Accumulation of precipitation as snow takes place if the temperature is lower than a threshold temperature TT, which normally is close to $0^{\circ} \mathrm{C}$. Melting of snow $\left(\mathrm{Qsn}_{t}\right)$ starts if the daily temperature $T_{t}>\mathrm{TT}$, and is calculated using a degree-day model; i.e., the daily temperature difference $\left(T_{t}-\mathrm{TT}\right)$ is multiplied by the parameter CFMAX $\left(\mathrm{mm}^{\circ} \mathrm{C}^{-1} \mathrm{day}^{-1}\right)$ to yield the daily amount of snowmelt. All precipitation that falls as snow in the model is multiplied by a correction factor, SFCF, to account for snow losses (e.g., sublimation). The snowpack retains meltwater until the amount exceeds a certain threshold (CWH, defined as a fraction of the water equivalent of the snowpack). When the temperature $T_{t}$ decreases below TT, water in the snowpack refreezes, and this process is controlled by the parameter CFR and the temperature difference $\left(\mathrm{TT}-T_{t}\right)$.

Potential evapotranspiration $\left(\mathrm{ETp}_{t}, \mathrm{mmday}^{-1}\right)$ was computed by multiplying the daily reference evaporation $\left(\mathrm{ETo}_{t}\right.$, mmday $^{-1}$ ) according to Penman-Monteith (Allen et al., 1998) with time-dependent crop factors. Crops transpire at a potential rate as long as $\mathrm{SS}_{t}$ is between soil moisture storage at field capacity $\left(\mathrm{SS}_{\mathrm{FC}}\right)$ and critical soil moisture storage $\left(\mathrm{SS}_{\mathrm{CR}}\right)$, implying that $\mathrm{ETa}_{t}=\mathrm{ETp}_{t}$. For drier conditions, $\mathrm{ETa}_{t}$ becomes less than $\mathrm{ETp}_{t}$ and is calculated by multiplying ETp $\mathrm{E}_{t}$ with the factor $\left(\mathrm{SS}_{t}-\mathrm{SS}_{\mathrm{WP}}\right) /\left(\mathrm{SS}_{\mathrm{CR}}-\mathrm{SS}_{\mathrm{WP}}\right)$, where $\mathrm{SS}_{\mathrm{WP}}$ is soil moisture storage at wilting point. $\mathrm{ETa}_{t}=$ 0 when the soil is drier than wilting point.

The downward flux from the soil to the groundwater $\left(\mathrm{Qs}_{t}\right)$ is simulated as

$$
\begin{aligned}
& \mathrm{Qs}_{t}=\mathrm{SS}_{t}-\mathrm{SS}_{\mathrm{FC}} \quad \text { if } \mathrm{SS}_{t} \geq \mathrm{SS}_{\mathrm{FC}} \\
& \mathrm{Qs}_{t}=\left(\frac{\mathrm{SS}_{t}-\mathrm{SS}_{\mathrm{CR}}}{\mathrm{SS}_{\mathrm{FC}}-\mathrm{SS}_{\mathrm{CR}}}\right)^{b} \cdot k_{\mathrm{FC}} \quad \text { if } \mathrm{SS}_{\mathrm{CR}}<\mathrm{SS}_{t}<\mathrm{SS}_{\mathrm{FC}} \\
& \mathrm{Qs}_{t}=0 \quad \text { if } \mathrm{SS}_{t} \leq \mathrm{SS}_{\mathrm{CR}},
\end{aligned}
$$

where $k_{\mathrm{FC}}$ is unsaturated hydraulic conductivity at field capacity $\left(\mathrm{mmday}^{-1}\right)$ and $b(-)$ is a shape parameter that is derived from the soil moisture retention and the unsaturated hydraulic conductivity curves.

Equation (4), which uses a power function to simulate recharge for soils drier than field capacity, is similar to the response function of the HBV model (Seibert, 2005). Rainfall bypassing the soil and directly feeding the groundwater system $\left(\mathrm{Qb}_{t}\right)$ may occur in dry clay-rich soils (e.g., Van
Stiphout et al., 1987; Bronswijk, 1988). This is accounted for by assuming that $\mathrm{Qb}_{t}$ takes place if $\mathrm{SS}_{t}<\mathrm{SS}_{\mathrm{CR}}$, and the bypassing rainfall is set equal to a fixed fraction of the rainfall (Sect. 2.3.3):

$$
\mathrm{Rch}_{t}=\mathrm{Qs}_{t}+\mathrm{Qb}_{t} .
$$

\subsubsection{Groundwater model}

Simulated recharge (Eq. 6) is input to a lumped groundwater model (non-shaded part of Fig. 1) based upon linear reservoir theory. This model was applied to simulate time series of groundwater discharge into a stream (Van Lanen et al., 2004a). The groundwater model uses the De ZeeuwHellinga approach (Kraijenhof van de Leur, 1962; Ritzema, 1994):

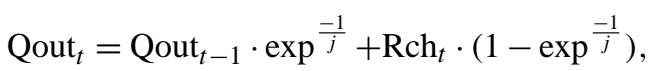

where Qout is groundwater discharge $\left(\mathrm{mmday}^{-1}\right)$ and $j$ is a response parameter (day). The groundwater discharge is hereafter called discharge. For naturally drained aquifers, a general interpretation of the response parameter is (Birtles and Wilkinson, 1975)

$j=\frac{\mu \cdot L^{2}}{\mathrm{kD}}$,

where $\mathrm{kD}$ is transmissivity of the groundwater system $\left(\mathrm{m}^{2}\right.$ day $\left.^{-1}\right), \mu$ storage coefficient of the groundwater system $(-)$, and $L$ distance between streams (m). These three parameters allow the calculation of the response parameter for a given groundwater system (e.g., quickly responding, slowly responding).

\subsubsection{Drought identification}

Hydrological drought characteristics (e.g., duration, severity) were derived from the simulated time series of daily discharge (Qout) using the threshold level approach (Yevjevich, 1967; Zelenhasic and Salvai, 1987; Tallaksen et al., 1997; Fleig et al., 2006). The threshold level for discharge was derived from the flow duration curve (i.e., the 80 percentile, Q80, was selected for drought identification). In case of perennial streams, thresholds in the range 70 to 95 percentile are considered reasonable (e.g., Hisdal et al., 2004). A monthly varying threshold level (Q80(i), where " $i$ " is the month number) was here chosen similar to many other drought studies (e.g., Hisdal et al., 2004; Van Lanen and Tallaksen, 2007). The discrete monthly threshold values were then smoothed and converted to daily thresholds by applying a centered moving average of 30 days (Van Loon et al., 2010). The drought duration (DD) is defined as the length (in days) of the period when the variable is below the threshold and the deficit volume equals the cumulative deviation from the threshold over the duration of the event. The deficit volume was standardized by the mean discharge (standardized 
deficit volume, SDV). Droughts starting before the period to be analyzed or continuing after the end of the period were excluded. If a particular month has zero flow for more than $20 \%$ of the years, Q80 for this month equals zero and no drought can be identified for this particular month. If for all 12 months $\mathrm{Q} 80=0$, then no drought can be identified at all. This happens regularly for grid cells in areas with ephemeral streams, i.e., areas with a hot arid climate or a very cold climate with permanent snow or ice. These grid cells were excluded from the analysis.

\subsection{Similarity index}

A similarity index (SI) was introduced as a quantitative measure of agreement between drought characteristics obtained for different realizations. The SI was used to investigate the impact of climate, soils and groundwater systems on hydrological drought. It is defined as the degree of overlap (100\% indicates complete overlap and $0 \%$ no overlap) between probability fields of two different climate, soil, and groundwater system realizations. Bivariate probability distributions were introduced not to perform extreme value analysis as it is common in hydrological studies, but rather to investigate probability fields of drought duration and standardized deficit volume (DD-SDV fields) as a mean to quantify agreement between two realizations. Parametric bivariate probability distributions regularly have been applied to study drought characteristics (e.g., Ashkar et al., 1998). However, these may not reveal significant relationships among drought characteristics under a wide range of environmental conditions as they are site-specific. Therefore, similar to Kim et al. (2003), non-parametric kernel density estimators (e.g., Wand, 1994; Wand and Jones, 1995) were adopted to determine smoothed bivariate probability fields of drought characteristics, i.e., the joint probability density field of drought duration and standardized deficit volume. The approach of Wand and Jones (1995) was used to determine the level of smoothing. The $90 \%$ probability field $(90 \%$ DD-SDV probability field) rather than the whole density field was chosen to define SI for various combinations of climate, soil and groundwater system to ensure that the analysis was not too much affected by rare events.

A straightforward geometrical approach was adopted to determine the degree of overlap of the $90 \%$ DD-SDV probabilities of two realizations. A rectangular field of $m \cdots n$ pixels was defined, in which all possible $90 \%$ DD-SDV probability fields of climate, soil and groundwater system realizations fit. The similarity index (SI) quantifies the degree of overlap (\%) between two $90 \%$ DD-SDV probability fields as follows:

$\mathrm{SI}=\frac{\mathrm{R} 1 \mid \mathrm{R} 2}{\mathrm{R} 1} \cdot 100$

$\mathrm{R} 1=\sum_{x=1}^{m} \sum_{Y=1}^{n} \operatorname{MR} 1(m, n) \quad$ if $\quad \operatorname{MR} 1(m, n)=1$

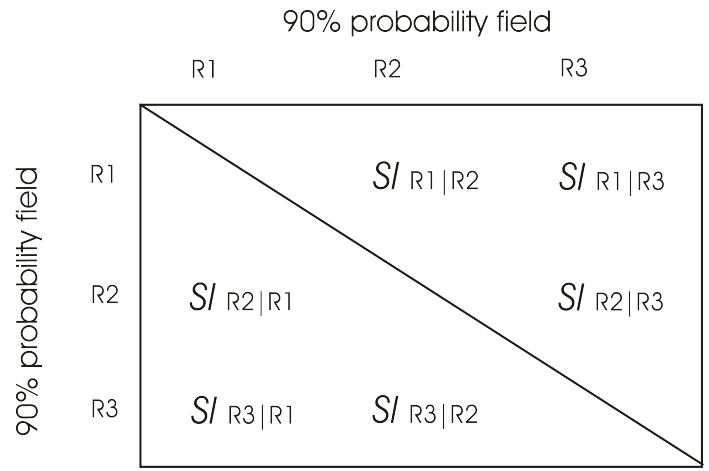

Fig. 2. Cross table showing the number of possible SI cases when comparing three realizations R1, R2 and R3.

$$
\begin{array}{r}
\mathrm{R} 1 \mid \mathrm{R} 2=\sum_{x=1}^{m} \sum_{Y=1}^{n} \operatorname{MR} 1(m, n) \quad \text { if } \quad \operatorname{MR} 1(m, n)=1, \\
\text { and } \operatorname{MR} 2(m, n)=1
\end{array}
$$

where R1 is the $90 \%$ DD-SDV probability field of climate, soil and groundwater system realization 1 , and $\mathrm{R} 1 \mid \mathrm{R} 2$ is the coinciding $90 \%$ DD-SDV probability fields of climate, soil and groundwater system realizations 1 and 2. MR1 and MR2 are matrices: MR1 contains the conditional probabilities of climate, soil and groundwater system realization 1, and MR2 the field of climate, soil and groundwater system realization 2. $\operatorname{MR} 1(m, n)$ and $\operatorname{MR} 2(m, n)$ are binary quantities where 1 equals a value within, and 0 a value outside the $90 \%$ DDSDV probability field of realizations 1 and 2 , respectively. In this study $m \cdot n$ was set at $150 \cdot 150$.

A low SI implies that the $90 \%$ DD-SDV probability field of the first realization substantially differs (in size and/or orientation) from the $90 \%$ DD-SDV probability field of the second realization. This means that a significant number of DDSDV combinations of realization 1 do not occur in realization 2. Hence the impact of climate and/or physical catchment structure of realization 1 on hydrological drought deviates from that presented by realization 2 , which implies that the controls of the two realizations are different. On the contrary, a high SI represents a climate, soil, and groundwater system realization (realization 1) that has a high number of DD-SDV combinations that also occur in realization 2 .

When two (partly) overlapping realizations were compared, first the $90 \%$ DD-SDV probability field of realization R1 was conditioned on realization R2 (SI R1|R2, Fig. 2). Next, the $90 \%$ DD-SDV probability field of realization R2 was conditioned on that of realization R1 (SI R2|R1). These cases led to different SIs. A special case is that R1 is a subset of R2, and R2 is a superset of R1. Figure 2 provides an example of the number of possible cases when three realizations were compared. These different cases were considered when the median, minimum and maximum SI were determined from the intercomparison of realizations (Sect. 2.3). 


\subsection{Data}

\subsubsection{Climatic data}

Climatic data were derived from a global dataset, i.e., WATCH Forcing Data (WFD, Weedon et al., 2011), which has been made available through the EU-FP6 project WATCH (WATer and global CHange). This large-scale dataset consists of gridded time series of meteorological variables (e.g., rainfall, snowfall, temperature, wind speed) on a daily basis for the period 1958-2001. The data have a half-degree resolution and are available for 67420 land grid cells. The WFD originate from modification (bias correction) of the ECMWF ERA-40 reanalysis data (Uppala et al., 2005), which are daily data on a 1.125 degree spatial resolution. The ERA-40 data were interpolated to a half-degree global land grid (excluding Antarctica). Among others, the $2 \mathrm{~m}$ temperature and specific humidity were corrected for elevation differences between the $1.125^{\circ}$ ERA-40 grid and the $0.5^{\circ} \mathrm{WFD}$ grid. Average diurnal temperature range and average temperature were bias-corrected using Climatic Research Unit (CRU) data. Furthermore, the monthly number of "wet" days was bias-corrected using CRU data (Mitchell and Jones, 2005) and precipitation totals using GPCCv4 (Schneider et al., 2011).

In this study, WFD rainfall and snowfall data were added up to obtain daily total precipitation $\left(\mathrm{Pra}_{t}+\mathrm{Psn}_{t}\right.$, Fig. 1). The hydrological model is based on the HBV approach (Sect. 2.1). Daily temperature $T_{t}$, which was retrieved from WFD, was used in combination with a predefined threshold temperature TT to determine whether precipitation falls as rainfall or snow. Daily minimum and maximum temperature were computed using the WFD 3-hourly temperature data. WFD (i.e., temperature, wind speed, altitude) were also used to compute daily reference evaporation (ETo) following the Penman-Monteith equation (e.g., Allen et al., 1998). Radiation from the WFD was not used because of inconsistencies in the daily meteorological data that are relevant for the computation of ETo (Melsen et al., 2011). Hence, net radiation used to compute ETo was derived from the WFD daily minimum and maximum temperatures. The latitude was used to compute extraterrestrial radiation (Allen et al., 1998).

Parameters to model snow accumulation and melt (Sect. 2.1) were set following the recommendations by Seibert $(2000,2005)$ and Masih et al. (2010), who provide standard parameter values and their range. Here, the threshold temperature TT was set at $0^{\circ} \mathrm{C}$ and the degree-day parameter CFMAX was assumed equal to $3.5 \mathrm{~mm}^{\circ} \mathrm{C}^{-1}$ day $^{-1}$, which reflects open landscape conditions. Snow losses (e.g., sublimation) were assumed to be $20 \%$, i.e., $\mathrm{SFCF}=0.8$, and the meltwater holding capacity $(\mathrm{CWH})$ and the refreezing coefficient (CFR) were set at 0.1 and 0.05 , respectively.

\subsubsection{Selection of grid cells using the Köppen-Geiger climatic map}

The hydrological model was run for a high number of randomly selected land grid cells, representing the five KöppenGeiger major climate types (Kottek et al., 2006; Peel et al., 2007). Prior to the selection of the grid cells, the KöppenGeiger map was recomputed using the $44 \mathrm{yr}$ of WFD climate data. The map of Kottek et al. (2006) could not be used since the WFD used other data sources and procedures (Weedon et al., 2011). The recomputation led to a change of subclimates in about $9 \%$ of the grid cells of the revised KöppenGeiger map. The area with arid climates slightly increased at the account of snow, and warm and temperate climates (Wanders et al., 2010).

The minimum number of grid cells (i.e., sample size) required to determine if two $90 \%$ DD-SDV probability fields (Sect. 2.2) significantly deviate was assessed using bootstrapping for each major climate type, soil and groundwater system realization. This method for assigning a level of reliability to the sample estimate was adopted because the theoretical bivariate distribution function of drought duration and standardized deficit volume for the different realizations is unknown. The similarity index (SI), i.e., the degree of overlap between the areas of the two $90 \%$ DD-SDV probability fields, was also used as a measure for this purpose. Our approach implied a step by step increase of the sample size by adding grid cells. If the SI of a particular sample size and the previous size approaches $100 \%$, then the sample size is assumed to be large enough. Each time one grid cell from the same climate, soil and groundwater system realization was added, the $90 \%$ DD-SDV probability field was computed. Next, the SI between the current and previous sample was determined (Eq. 9). These sampling steps were carried out 39 times (last sample contained all drought events from 40 grid cells). This was repeated 40 times for the same climate, soil and groundwater system realization, but retrieving different grid cells. Finally, the 5\% quantile (5\% lowest SI) was derived for each of the 39 sampling steps from the 40 series of SI. If the $5 \%$ quantile of SI among two subsequent samples was higher than $97.5 \%$, it was assumed that sample size is sufficiently large to conclude that the difference between the samples is not significant (i.e., they come from the same population). In this way the minimum number of grid cells was estimated for each climate, soil and groundwater system realization (in total 45).

The resampling approach showed that around 30 grid cells were needed to be sampled to satisfy the criterion that the $5 \%$ quantile of SI among two samples is higher than $97.5 \%$. The only exception is the polar climate where slightly more grid cells were required. To comply with the requirements set by the bootstrapping and to ensure that all 31 KöppenGeiger climate subtypes were represented, eventually, a total of 1495 grid cells were selected (about $2.2 \%$ of all grid cells), well distributed over the globe (Appendix Fig. A1). 
Table 1. Distribution of the selected grid cells over the KöppenGeiger climate types.

\begin{tabular}{llc}
\hline \multicolumn{2}{c}{ Major climate type } & Number of cells \\
\hline A & Equatorial climates & 235 \\
B & Arid climates & 313 \\
C & Warm temperate climates & 242 \\
D & Snow climates & 506 \\
E & Polar climates & 199 \\
\hline
\end{tabular}

Table 1 gives the number of selected grid cells per major climate type. The highest number of grid cells (34\%) was selected for the snow climate (D-climate). The other major climate types (A, B, C and E) were represented by $16 \%, 21 \%$, $16 \%$ and $13 \%$ of the grid cells, respectively. These numbers are well above the minimum number as specified through the bootstrapping. When comparing $90 \%$ DD-SDV probability fields of two different climate, soil and groundwater system realizations, this number of cells ensures that a SI lower than $97.5 \%$ is not caused by the sample size, but by differences in either the climate, soil or groundwater system (hereafter called significant difference).

\subsubsection{Physical catchment structure}

In total, nine realizations for the physical catchment structure were distinguished consisting of three mineral soils and three groundwater systems. Land use was assumed to be identical for all realizations, i.e., permanent grassland with a rooting depth of $50 \mathrm{~cm}$. The soil information was derived from a standard series of existing soils that predominantly differ in soil texture (Wösten et al., 2001a, b). Each heterogeneous soil was assumed to consist of a $30 \mathrm{~cm}$ topsoil overlying a $20 \mathrm{~cm}$ thick subsoil with different soil moisture retention characteristics. The moisture retention data were used to select representative soils with a medium soil moisture supply capacity (light silty loam soil, hereafter Soil II) and soils with low and high supply capacity, i.e., a coarse sandy soil (Soil I) and a sandy loamy soil (Soil III), respectively (Table 2). Total available soil moisture $\left(\mathrm{SS}_{\mathrm{max}}=\mathrm{SS}_{\mathrm{FC}}-\mathrm{SS}_{\mathrm{WP}}\right)$ is 31.9 , 125.4 and $154.8 \mathrm{~mm}$ for Soils I, II and III, respectively, and readily available soil moisture $\left(\mathrm{SS}_{\mathrm{FC}}-\mathrm{SS}_{\mathrm{CR}}\right)$ is $28.4,73.7$ and $94.5 \mathrm{~mm}$. Soil II deviates about $+10 \%$ from the average total and readily available soil moisture computed for the standard series of 15 mineral soils. For Soils I and III the deviation is about -65 and $+40 \%$, respectively. Clearly the loamy soils (II and III) are more similar than the coarse sandy soil (Soil I) because of the skewed distribution of the soil moisture supply capacity over the soil textures. Mineral soils were only considered because peat soils cover only a small area on the globe. Rainfall $\left(>2 \mathrm{~mm} \mathrm{day}^{-1}\right.$ ) bypassing the dry soil and directly feeding into the groundwater system (Eq. 6) was assumed to be equal to $50 \%$ of the rainfall and to occur when the soil is dryer than critical soil moisture storage $\left(\mathrm{SS}_{\mathrm{CR}}\right)$.

Three representative groundwater systems were defined through the response parameter $j$ (Eq. 8). Values of $j$ of 20 or 30 day are generally applicable to artificially drained fields and values of up to 2000 day to discharge from well-developed aquifers into streams (Peters, 2003). Comprehensive drainage studies are the basis for Eqs. (7) and (8) and associated $j$ values (Kraijenhof van de Leur, 1962; Ritzema, 1994). Here $j=250$ day was selected to represent an intermediately responding groundwater system. This, for example, holds for a catchment with a transmissivity of $1000 \mathrm{~m}^{2} \mathrm{~d}^{-1}$, a storage coefficient of 0.1 and a stream distance of about $1.5 \mathrm{~km}$. Quickly and slowly responding groundwater systems were defined through a response parameter of 100 and 1000 day, respectively, which still represent fairly common groundwater systems.

In summary, the proposed modeling framework was applied to nine realizations of physical catchment structure for each of the 1495 grid cells, representing a fair coverage of the different climates across the world and, thus, a realistic range of drought characteristics. The introduced framework provides a unique opportunity to explore the relative role of major climates, soils and groundwater systems on hydrological drought across the globe.

\section{Results}

\subsection{Importance of climate}

Drought duration and standardized deficit volume (DDSDV) for each drought event were derived from the simulated time series of discharge for each of the selected grid cells (Table 1). First this was done for grid cells with a soil of medium soil moisture supply capacity (Soil II) and an intermediately responding groundwater system $(j=250$ day), hereafter called the reference situation. The drought durations and standardized deficit volumes of all grid cells belonging to a certain Köppen-Geiger major climate type were then collated to calculate summary drought statistics (Fig. 3). Figure 3a shows that the lowest number of droughts is found in the B- and E-climates. A low number of droughts implies longer duration droughts, following the use of a percentile as threshold level (the same number of drought days; Sect. 2.1). The 95 decile (D95) reflects this better than the median due to the high number of short-duration droughts (minor droughts were not excluded from the analysis). The D95 duration is 297 and 272 days for the A- and C-climates, whereas it is substantially higher for the B- and E-climates (362 and 373 days). The standardized deficit volume for the major climate types shows a similar pattern. The D95 standard deficit volume of the B-and E-climates (52 to 67 times the mean daily discharge, respectively) is about twice as high as for the A- and C-climates (29 and 26 times the mean daily 
Table 2. Soil moisture characteristics of the three selected soils.

\begin{tabular}{|c|c|c|c|c|c|c|c|c|c|c|}
\hline \multirow{3}{*}{$\begin{array}{l}\text { Soil } \\
\text { Number }\end{array}$} & \multirow{3}{*}{ Texture } & \multicolumn{6}{|c|}{ Soil moisture content (vol. \%) } & \multirow{2}{*}{\multicolumn{3}{|c|}{$\begin{array}{l}\text { Soil moisture supply } \\
\text { capacity }(\mathrm{mm})\end{array}$}} \\
\hline & & \multicolumn{3}{|c|}{ Topsoil } & \multicolumn{3}{|c|}{ Subsoil } & & & \\
\hline & & $\mathrm{FC}$ & $\mathrm{CR}$ & WP & $\mathrm{FC}$ & $\mathrm{CR}$ & WP & $\mathrm{SS}_{\mathrm{FC}}$ & $\mathrm{SS}_{\mathrm{CR}}$ & $\mathrm{SS}_{\mathrm{WP}}$ \\
\hline I & $\begin{array}{l}\text { coarse } \\
\text { sand }\end{array}$ & 9.4 & 2.0 & 1.1 & 4.2 & 1.1 & 0.7 & 36.6 & 8.2 & 4.7 \\
\hline II & $\begin{array}{l}\text { light silty } \\
\text { loam }\end{array}$ & 31.5 & 19.0 & 9.5 & 37.2 & 19.1 & 7.5 & 168.9 & 95.2 & 43.5 \\
\hline III & $\begin{array}{l}\text { sandy } \\
\text { loam }\end{array}$ & 35.3 & 16.8 & 5.7 & 36.2 & 16.7 & 3.2 & 178.3 & 83.8 & 23.5 \\
\hline
\end{tabular}
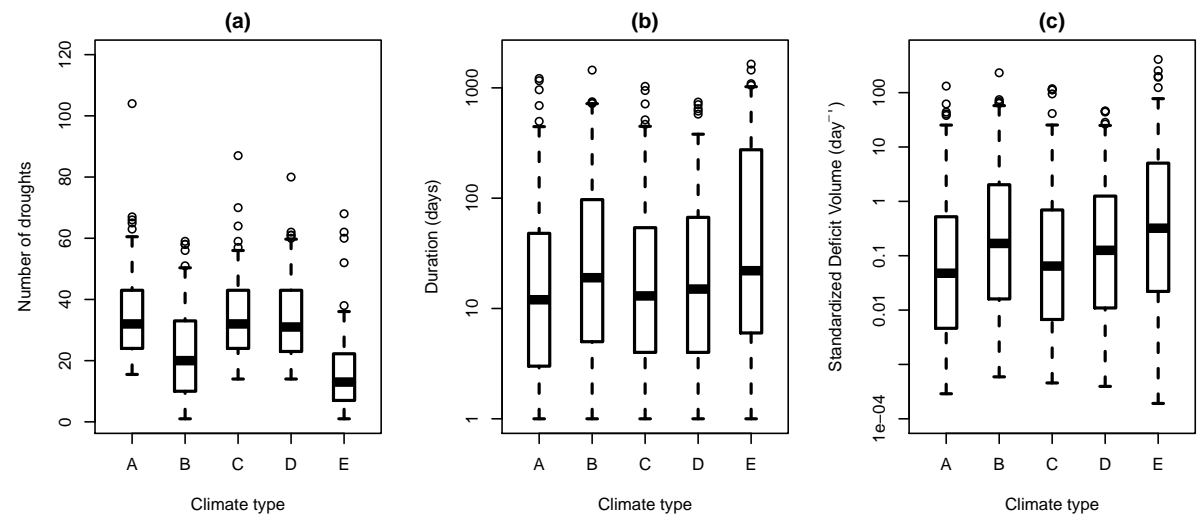

Fig. 3. Summary statistics (box: 25,50 and 75 deciles, whiskers: 5 and 95 deciles) of hydrological drought characteristics of all drought events for each of the major climate types (A-E); Soil II and groundwater system $j=250$ day, period 1958-2001. (a) number of droughts, (b) drought duration, and (c) standardized deficit volume. The circles represent extreme events beyond D95 for the 96, 97, 98, 99 and 100 deciles. Please note that y-axis of (a) is on linear scale, and (b) and (c) are on log scale.

discharge, respectively). The snow climate (D-climate) takes an intermediate position (33 times the mean daily discharge).

The $90 \%$ DD-SDV probability field based on drought events of each Köppen-Geiger major climate type is shown in Fig. 4 for the reference situation. The $90 \%$ DD-SDV probability fields share a vast common area (implying a high SI), which would suggest a rather limited influence of climate on hydrological drought characteristics. However, there are also clear differences. The areas of the $90 \%$ DD-SDV probability fields of the temperate and equatorial climates (types $\mathrm{A}$ and C) are significantly smaller than those of the arid and polar climates (types B and E), which is consistent with the conclusion of the summary statistics (Fig. 3). The area of the snow climate (type D) again takes an intermediate position.

The similarity index (SI), used to quantify the degree of similarity between the $90 \%$ DD-SDV probability fields of two realizations, is calculated for the different climate types, as shown in Table 3. The SI for all major climates, except E-climates, is at least $65 \%$ and usually over $75 \%$ (only row-wise reading), which demonstrates a rather high similarity among most major climate types. The relatively small $90 \%$ DD-SDV probability field of the temperate climate (Fig. 4, type C) largely coincides with the $90 \%$ DD-SDV probability fields of the other climates. This leads to the highest SI; i.e., $96 \%$ or more of the $90 \%$ DD-SDV probability field of type $\mathrm{C}$ overlaps with the fields of the others. This means that combinations of drought duration and standardized deficit volume that occur in the temperate climate also happen in the other major climate types. The equatorial climate (type A) also has high SIs $(\geq 90 \%)$. The polar climate (type E) has the lowest SIs (54-73\%). The other extreme climate, the arid climate (type B), has also relatively lower SI, in particular with climate types A and C, i.e., 70 and $65 \%$, respectively. The high SI of the A- and C-climates when conditioned on the B- and E-climates and the rather low SI of the B- and E-climates when conditioned on the A- and Cclimates demonstrates the larger spread in drought characteristics of the B- and E-climates, which is consistent with the summary statistics (Fig. 3). This also holds for the intermediate position of the snow climate (type D), which has only $75-79 \%$ of combinations of drought duration and standardized deficit volumes that also occur in climate types A and C. 
Table 3. Similarity index $\left(\mathrm{SI}^{\mathrm{a}}\right)(\%)$ for the Köppen-Geiger major climate types for catchments with a medium soil water supply capacity (Soil II) and intermediately responding groundwater system $(j=250 \mathrm{~d})$.

\begin{tabular}{llllll}
\hline $\begin{array}{l}\text { Major } \\
\text { climate }\end{array}$ & A & Major climate type $Y$ \\
type $X$ & & & C & D & E \\
\hline A & 100 & $99^{\mathrm{b}}$ & 90 & 93 & 100 \\
B & $70^{\mathrm{b}}$ & 100 & 65 & 82 & 95 \\
$\mathrm{C}$ & 96 & 100 & 100 & 96 & 99 \\
$\mathrm{D}$ & 79 & 98 & 75 & 100 & 99 \\
$\mathrm{E}$ & 54 & 73 & 50 & 64 & 100 \\
\hline
\end{tabular}

${ }^{\text {a }} \mathrm{SI}<97.5 \%$ implies that the difference is caused by climate and cannot solely be explained by the sample size. $\mathrm{SI}=100 \%$ means that the drought durations and the standardized deficit volumes of two climates completely overlap; i.e., the two climates have the same effect on these drought characteristics (Sect. 2.3). ${ }^{\mathrm{b}}$ Rows give the degree of overlap of climate type $X$ with $Y$, i.e., $\mathrm{SI}(\mathrm{X} \mid \mathrm{Y})$; for example, $\mathrm{SI}(\mathrm{A} \mid \mathrm{B})=99$ means that A overlaps $99 \%$ with $\mathrm{B}$, and $\mathrm{SI}(\mathrm{B} \mid \mathrm{A})=70$ means that $\mathrm{B}$ overlaps $70 \%$ with $\mathrm{A}$ (thus the area of $B>A$; see Fig. 4).

\subsection{Importance of soils and groundwater systems}

The impact of climate on drought characteristics was discussed in the previous section for a reference physical catchment structure, i.e., with a soil having a medium soil moisture capacity (Soil II) and an intermediately responding groundwater system $(j=250$ day). In this section the effect of the physical catchment structure is analyzed. Summary statistics of drought characteristics of all selected grid cells for each of the nine soil and groundwater system realizations are given in Fig. 5, irrespective of climate type (i.e., all climates lumped). It shows that the number of droughts, duration and standardized deficit volume are hardly affected by the soil moisture supply capacity for the selected moderately thick soils covered with permanent grassland (Table 2). On the contrary, the responsiveness of the groundwater system has a major impact on hydrological drought characteristics, in particular on the number of droughts (all deciles). The median number of droughts (D50) for a quickly responding groundwater system $(j=100$ day $)$ is about three times higher than for a slowly responding system ( $j=1000$ day) (upper row). The range (D75-D25) in the number of droughts is twice as high for the quickly responding system. Differences in median drought duration are rather small (many minor droughts), but the lower number of droughts for the slowly responding system results in a D75 duration that is about twice as long as for a quickly responding system (middle row). Similar to drought duration, differences in standardized deficit volume between groundwater systems are not clearly seen in the median plotted on a log scale (lower row). However, larger differences can be seen for the higher deciles. The D75 standardized deficit volume of the quickly responding systems

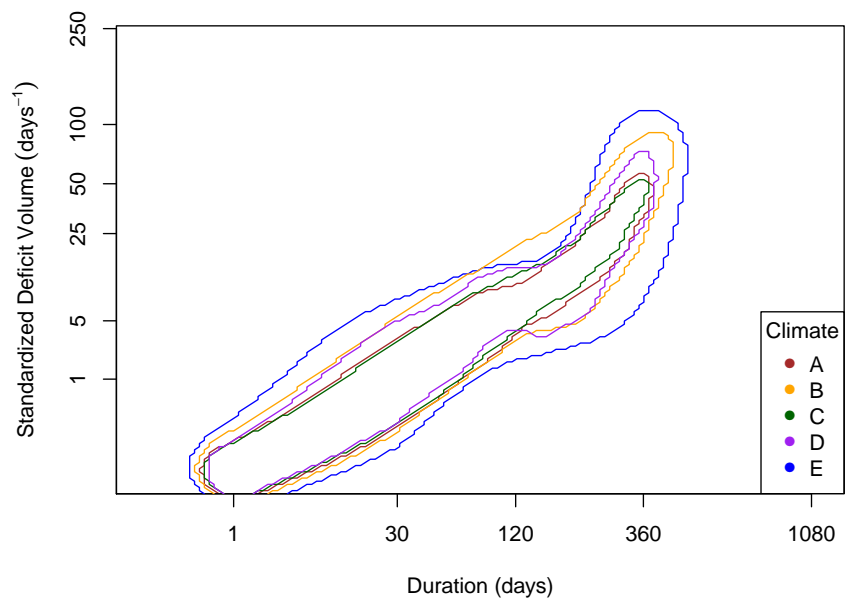

Fig. 4. $90 \%$ bivariate probability fields of hydrological drought duration and standardized deficit volume for the five Köppen-Geiger major climate types (A-E) for the reference situation (i.e., a medium soil water supply capacity (Soil II) and intermediately responding groundwater system $(j=250 \mathrm{~d})$ ). We used the double square root of the drought duration because of the wide spread of the durations (the kernel smoothing, Sect. 2.2, allows drought durations smaller than one day).

is about two and half times higher than that of the slowly responding system.

The relation between the drought duration and standardized deficit volume for all climates lumped is plotted for a number of deciles in Fig. 6. The small influence of the selected soils and the large impact of groundwater systems, in particular on the duration, are here confirmed. The lines for the three soils more or less coincide, whereas these clearly deviate for the three groundwater systems. The patterns seen for the five Köppen-Geiger climate types are more or less similar and almost identical to the lumped one (upper left). The patterns for the equatorial, temperate and snow climates (A-, C- and D-climates) are most similar to the lumped one. The patterns for the more extreme climates (arid and polar, B- and E-climates) deviate more, in particular for the groundwater systems with a quicker response $(j=100$ and 250 day).

The influence of soil type on the $90 \%$ DD-SDV probability fields was also investigated through the similarity index (SI) derived separately for each of the three groundwater systems and five major climates (Table 4). The table shows the median SI of the six possible combinations of three soils (Fig. 2) for a particular climate type and groundwater system realization. The minimum and maximum SI were also determined from the six possible combinations. For example, the median SI for the equatorial climates (A-climate) and quickly responding groundwater system $(j=100$ day) is $96 \%$, implying that the median of the six SIs for the three soils with the A-climate and $j=100$ day is $96 \%$. The difference between the minimum and maximum SI is rather 

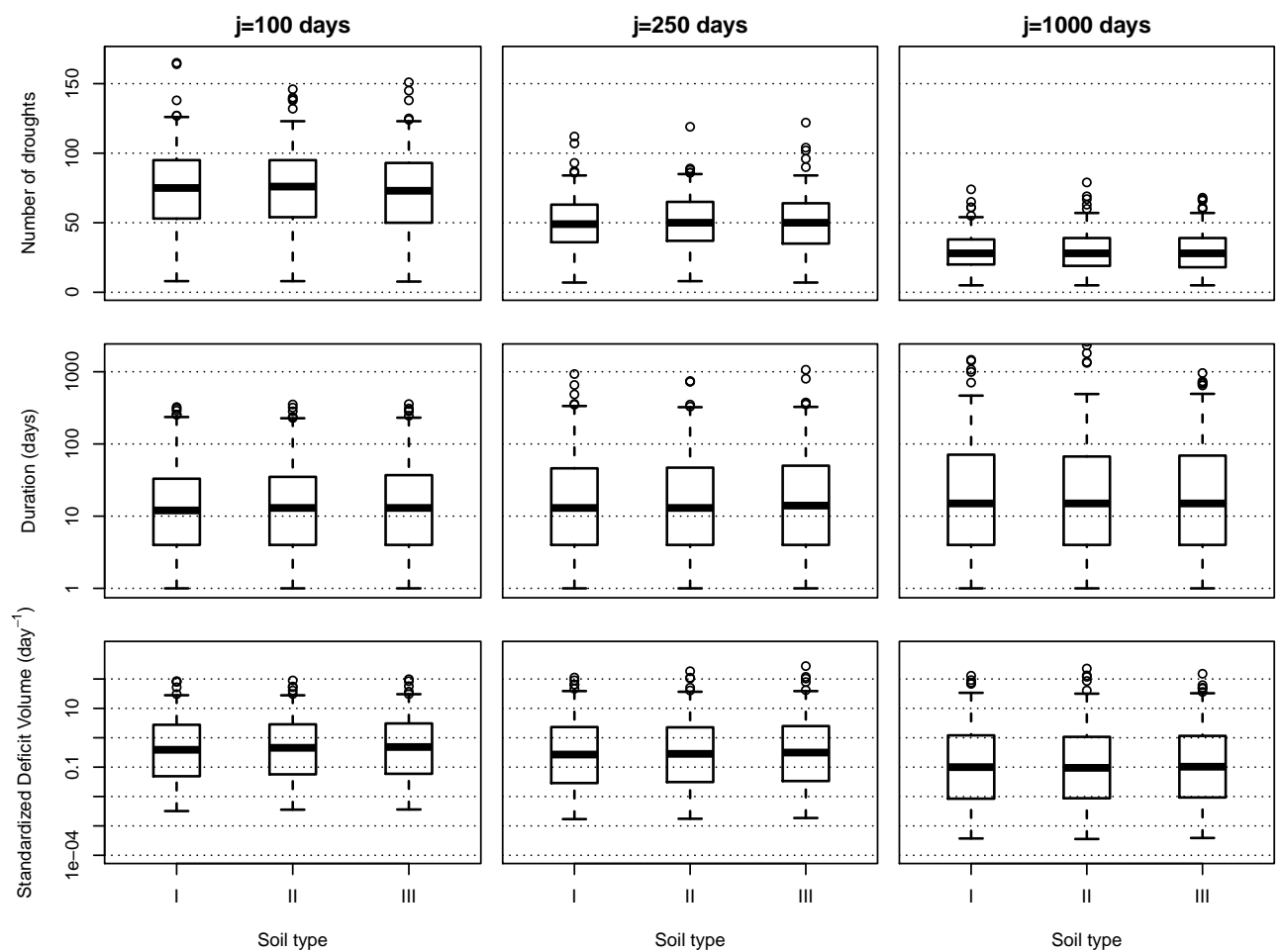

Fig. 5. Summary statistics (box: 25, 50 and 75 deciles, whiskers: 5 and 95 deciles) of hydrological drought characteristics (number of droughts, drought duration, standardized deficit volume) of all drought events (1495 grid cells) for three soils and three different groundwater systems. The circles represent extreme events beyond D95 for the 96, 97, 98, 99 and 100 deciles. Please note that y-axis is on log scale.
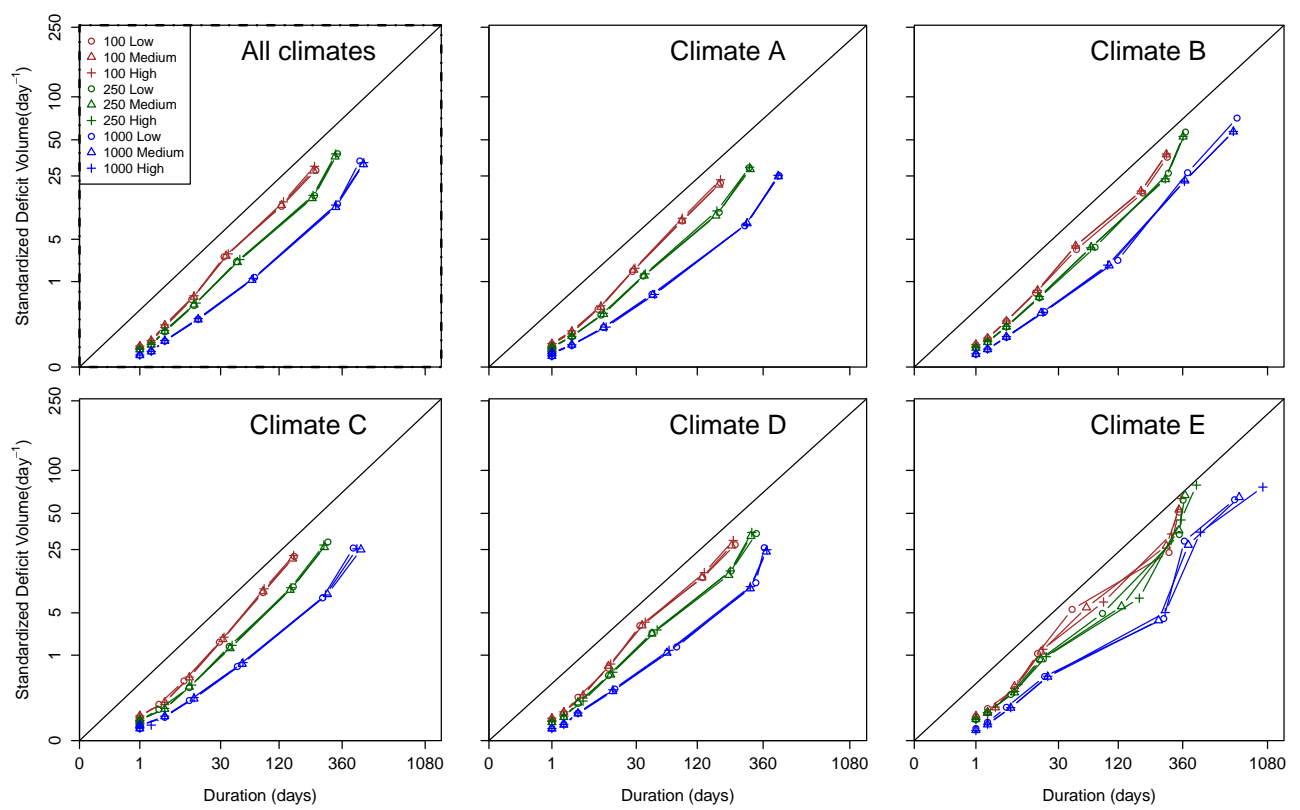

Fig. 6. Drought duration and standardized deficit volume $(5,10,25,50,75,90$ and 95 deciles) for three soils and three different groundwater systems lumped for all climates and for each of the five Köppen-Geiger major climate types (A-E). The circles represent extreme events beyond D95 for the 96, 97, 98, 99 and 100 deciles. Please note that y-axis is on log scale. 
small (96-98\%). For the intermediately and slowly responding groundwater systems $(j=250$ and 1000 day), the median SI is at least $93 \%$ and in most cases $96 \%$ or higher, which shows that the $90 \%$ DD-SDV probability fields of the various soils almost completely overlap, so that the influence of the selected soils on hydrological drought characteristics is rather limited. The impact is somewhat higher for the quickly responding groundwater system $(j=100$ day), in particular for the polar climates (E-climate), i.e., median SI $=91 \%$. Most of the SIs in Table 4 are high, meaning that the $90 \%$ DD-SDV probability fields do not deviate much, although these small deviations are still significant $(<97.5 \%$, Sect. 2.3).

Similarly as for the soils, the influence of the responsiveness of the groundwater system on the SI is determined (Table 5) for each of the three soils and five major climates separately. In this case, the median SI is found out of the six possible combinations of three groundwater systems (Fig. 2) for a particular climate type and soil realization. The minimum and maximum SI are also provided. All SIs are below $80 \%$ (except maximum SI for the B- and E-climates), meaning that the $80 \%$ DD-SDV probability fields of the various groundwater systems deviate significantly. The lowest SI ( $33 \%$ ) is found when comparing the $90 \%$ DD-SDV probability fields of the quickly and slowly responding groundwater systems ( $j=100$ and 1000 day) for Soil II and climate C, whereas the maximum SI (88\%) is found for the fields of the quickly and intermediately responding groundwater systems ( $j=100$ and 250 day) for Soil III and E-climate.

\subsection{Sensitivity analysis}

Additional sensitivity analyses for the reference situation (Soil II, $j=250$ day) demonstrated that the selected parameterizations (i.e., land use and snow) of the conceptual hydrological model (Sect. 2.3) only had limited influence on the obtained SI (Sect. 3.1). In the land use sensitivity analysis, the permanent grassland was replaced by more taller permanent vegetation type having a $10 \%$ higher potential evapotranspiration (e.g., shrubs, trees). This also meant a larger rooting depth, which was increased from $0.50 \mathrm{~m}$ (Sect. 2.3) to $1.50 \mathrm{~m}$. Although land use had impact on simulated discharge and the $90 \%$ DD-SDV probability field, the SIs of the major climate types only showed a minor change compared to the reference situation (around $2 \%$ for the A-, C- and Dclimates, and around $6 \%$ for the more extreme B- and Eclimates, compared to Table 3 ). In the snow sensitivity analysis, two additional snow parameter sets selected within the normal parameter range (Seibert, 2000, 2005; Seibert et al., 2000; Widén-Nilsson et al., 2007; Van der Knijff and De Roo, 2008; Masih et al., 2010) were defined to investigate the influence on SI. The first set resulted into earlier snow accumulation and later melt $\left(\mathrm{TT}=1.0^{\circ} \mathrm{C}\right)$ and a slower snowmelt $\left(\mathrm{CFMAX}=2.0 \mathrm{~mm}^{\circ} \mathrm{C}^{-1} \mathrm{day}^{-1}\right)$. The second parameter set led to later accumulation and earlier melt $\left(\mathrm{TT}=-1.0^{\circ} \mathrm{C}\right)$ and faster snowmelt $\left(\mathrm{CFMAX}=4.5 \mathrm{~mm}^{\circ} \mathrm{C}^{-1} \mathrm{day}^{-1}\right)$. The analysis showed that the SIs of the major climate types changed only slightly compared to the reference situation in Table 3. For the scenario with less snow, the SIs did not deviate more than $1 \%$, whereas for the scenario with more snow the differences were somewhat larger (less than $1.5 \%$ for the A-, B- and C-climates, and 2.4 and $4.1 \%$ for the D- and Eclimates).

\section{Discussion}

\subsection{Climate control on hydrological drought}

The B- and E-climates have lower number of droughts, longer drought durations and larger standard deficit volumes than the other major climates (Fig. 3), because of very irregular rain (B type) or erratic snowmelt peaks that interrupt long snow accumulation periods (E type). This large interannual climate variability of the B- and E-climates (e.g., Stahl and Hisdal, 2004) gives rise to hydrographs with sustained periods of low discharge on which irregular sharp flow peaks are superimposed. On the contrary, the regular rain in the A- and C-climates prevents the development of long-lasting droughts with large standardized deficit volumes implying rather small $90 \%$ DD-SDV probability fields compared to those of the B- and E-climates (Fig. 4). These differences in the $90 \%$ DD-SDV probability fields among the climates are reflected in the SI (Table 3), i.e., high SIs for the A- and $\mathrm{C}$-climates and rather low for the B- and E-climates. The $90 \%$ DD-SDV probability fields of the snow climates (Dclimates) are larger than that of types $\mathrm{A}$ and $\mathrm{C}$, resulting in lower SI (Table 3). In the A- and C-climates drought development is strongly restricted by the seasons, whereas in the D-climate summer drought can continue into winter resulting in very long droughts (Van Loon and Van Lanen, 2012), which can be prolonged by delayed snowmelt. Drought in the $\mathrm{D}$-climate always ends by a snowmelt peak feeding soil moisture, groundwater storage $\left(\mathrm{SS}_{t}, \mathrm{SG}_{t}\right)$ and eventually discharge (Qout ${ }_{t}$, Fig. 1). These consistent peaks do not exist in the B- and E-climates, which are more irregular and, hence, lead to longer drought than in the D-climate.

\subsection{Catchment control on hydrological drought}

Hydrological drought is affected not only by climate, but also by catchment control, i.e., physical catchment structure (soil and groundwater system) as demonstrated in Sect. 3.2. The selected moderately thick soils under permanent grassland, which cover a range of soil moisture supply capacities, have limited effect on the hydrological drought characteristics, which is reflected in the high SI (Table 4) and confirmed by summary statistics (Fig. 5). This rather low sensitivity is caused by the limited impact of the selected soils on the temporal variability (intra- and interannual) of the hydrographs. Soils with strong preferential flow (e.g., hydrophobic soils 
Table 4. Impact of soils on the similarity index (SI) (\%) for the five Köppen-Geiger major climate types and three groundwater systems.

\begin{tabular}{|c|c|c|c|c|c|c|c|c|c|c|c|}
\hline \multirow[b]{3}{*}{$\begin{array}{l}j \\
\text { (day) }\end{array}$} & \multicolumn{11}{|c|}{ Major climate types } \\
\hline & \multicolumn{2}{|c|}{ A } & \multicolumn{2}{|c|}{ B } & \multicolumn{2}{|c|}{$\mathrm{C}$} & \multicolumn{2}{|c|}{$\mathrm{D}$} & \multicolumn{2}{|c|}{$\mathrm{E}$} & \multirow{2}{*}{$\begin{array}{c}\text { All } \\
\begin{array}{c}\text { Soil I, II and III } \\
\text { median }\end{array}\end{array}$} \\
\hline & $\begin{array}{r}\text { Soil I. } \\
\text { median }\end{array}$ & $\begin{array}{l}\text { II and III } \\
\text { min-max }\end{array}$ & $\begin{array}{l}\text { Soil I, } \\
\text { median }\end{array}$ & $\begin{array}{l}\text { II and III } \\
\text { min-max }\end{array}$ & $\begin{array}{r}\text { Soil I, } \\
\text { median }\end{array}$ & $\begin{array}{l}\text { I and III } \\
\text { min-max }\end{array}$ & $\begin{array}{l}\text { Soil I, } \\
\text { median }\end{array}$ & $\begin{array}{l}\text { I and III } \\
\text { min-max }\end{array}$ & $\begin{array}{c}\text { Soil I, } \\
\text { median }\end{array}$ & $\begin{array}{l}\text { I and III } \\
\text { min-max }\end{array}$ & \\
\hline 100 & 96 & $96-98$ & 96 & $96-99$ & 96 & 94-99 & 92 & $88-98$ & 91 & 77-97 & 96 \\
\hline 250 & 97 & 95-99 & 99 & 95-99 & 96 & 93-99 & 96 & 92-99 & 93 & 89-100 & 96 \\
\hline 1000 & 97 & 95-98 & 98 & $92-100$ & 97 & 95-98 & 97 & 89-99 & 95 & $93-100$ & 97 \\
\hline
\end{tabular}

or heavy clay soils) that were not included in this study may generate a more irregular discharge (e.g., Bouma et al., 2011) and, hence, might exhibit a more prominent role of soils on hydrological drought characteristics.

Responsiveness of groundwater systems has a large effect on drought characteristics (Fig. 5). Flashy hydrographs, associated with quickly responding groundwater systems, cause a high number of drought events of short durations. Hydrographs representative of slowly responding groundwater systems are rather smooth and do not show direct response to rainfall or snowmelt; i.e., the response is delayed and attenuated. Droughts in such hydrographs are rarer, but last longer. In our modeling experiment the median number of droughts for the quickly responding groundwater system is three times higher than that of the slowly responding system. These results are supported by earlier-documented sitespecific drought studies (e.g., Tallaksen et al., 1997; Peters et al., 2003; Van Lanen et al., 2004a, b; Fleig et al., 2006; Van Lanen and Tallaksen, 2007, 2008; Van Loon and Van Lanen, 2012) and by studies on the modification of climateriver flow associations by basin characteristics (e.g., Tague et al., 2008; Laize and Hannah, 2010). The larger influence of groundwater systems on hydrological drought characteristics compared to soils is also reflected in the substantially lower SIs of groundwater systems (Table 5). The somewhat smaller influence of the groundwater system in the extreme climates (B- and E-climates) is likely a result of the generally low recharge in these climates leading to low $\mathrm{SG}_{t}$ variation among the studied groundwater systems. Longer droughts, typical for slowly responding groundwater systems, do not always coincide with larger standardized deficit volumes (Fig. 5). A smooth discharge hydrograph results in smaller departures from the threshold (i.e., smaller deficits) compared to the more flashy hydrographs of the quickly responding groundwater systems. The net effect of longer durations but smaller departures from the threshold of the slowly responding groundwater systems leads to slightly lower standardized deficit volumes than those that can be found for the quickly responding systems. Whether the more long-lasting drought with less deficit or the short-lived with higher deficit has the more severe impacts depends on the affected sector (e.g., aquatic ecology or water supply). The simulated time series with the conceptual hydrological model provide potential to unravel effects of climate control versus physical catchment structure on reported trends in hydrological drought (e.g., Stahl et al., 2010, 2012; Hannaford et al., 2013). The model outcome can also be used to support studies on drought propagation (i.e., the conversion of a meteorological drought into a hydrological drought; e.g., Changnon, 1987; Peters et al., 2003; Tallaksen et al., 2009; Van Loon and Van Lanen, 2012), which also depends on climate and physical catchment structure.

\subsection{Modeling framework}

The modeling framework adopted in this study is based on a well-known concept for hydrological studies (combined soil water balance model and groundwater model) similar to the widely applied hydrological model HBV (e.g., Bergström, 1976; Seibert, 2000, 2005; Seibert et al., 2000). Tijdeman et al. (2012) explored the performance of the rather simple conceptual model adopted in this study against observations in four catchments with contrasting climate and physical catchment structure and compared the outcome to a more detailed hydrological model simulation. This exercise showed that a simple model can reasonably well simulate the streamflow hydrograph, except for the peak flows. However, here focus is on low flow situations, which in principle can be well simulated by a single reservoir model. Use of one single reservoir to represent groundwater (Fig. 1) was balanced through the inclusion of realizations with quickly responding groundwater system ( $j=100$ day) that represent flashy flow conditions. Thus, it can be assumed that the adopted model sufficiently represents key hydrological processes for simulating discharge. It is uncommon to calibrate hydrological models that are used to present results for all climates around the globe (e.g., Haddeland et al., 2011) because among others gridded databases with observed runoff are lacking. In this study, as an alternative, realizations of land use, soils and groundwater systems were introduced, based upon real world parameter settings. In general, hydrological models have demonstrated limitations and uncertainties if required to extrapolate data in space and time (i.e., discharge in this study) (e.g., Beven, 2007). The HBV model and similar model concepts have also been used for low flow and drought studies (e.g., Engeland and Hisdal, 2009; Van Loon et al., 2010; Van Huijgevoort et al., 2010; Wong et al., 2011; Van Loon and Van Lanen, 2012). These and other modeling 
Table 5. Impact of groundwater systems on the similarity index (SI) (\%) for five Köppen-Geiger major climate types and three soils.

\begin{tabular}{|c|c|c|c|c|c|c|c|c|c|c|c|}
\hline \multirow[b]{4}{*}{ Soil } & \multicolumn{11}{|c|}{ Major climate types } \\
\hline & \multicolumn{2}{|c|}{ A } & \multicolumn{2}{|c|}{ B } & \multicolumn{2}{|c|}{$\mathrm{C}$} & \multicolumn{2}{|c|}{$\mathrm{D}$} & \multicolumn{2}{|c|}{$\mathrm{E}$} & \multirow{3}{*}{$\begin{array}{c}\text { All } \\
j=100,250 \text { and } \\
\begin{array}{c}1000 \text { day } \\
\text { median }\end{array}\end{array}$} \\
\hline & \multicolumn{2}{|c|}{$\begin{array}{c}j=100,250 \text { and } \\
1000 \text { day }\end{array}$} & \multicolumn{2}{|c|}{$\begin{array}{c}j=100,250 \text { and } \\
1000 \text { day }\end{array}$} & \multicolumn{2}{|c|}{$\begin{array}{c}j=100,250 \text { and } \\
1000 \text { day }\end{array}$} & \multicolumn{2}{|c|}{$\begin{array}{c}j=100,250 \text { and } \\
1000 \text { day }\end{array}$} & \multicolumn{2}{|c|}{$\begin{array}{c}j=100,250 \text { and } \\
1000 \text { day }\end{array}$} & \\
\hline & median & $\min -\max$ & median & $\min -\max$ & median & $\min -\max$ & median & $\min -\max$ & median & $\min -\max$ & \\
\hline I & 48 & $37-72$ & 61 & $44-82$ & 49 & $36-74$ & 54 & $39-79$ & 72 & 59-86 & 60 \\
\hline II & 47 & $35-70$ & 58 & $42-81$ & 47 & $33-69$ & 50 & $34-75$ & 68 & $58-87$ & 58 \\
\hline III & 47 & $36-70$ & 57 & $43-80$ & 48 & $34-70$ & 51 & $41-79$ & 70 & $58-88$ & 57 \\
\hline
\end{tabular}

studies demonstrate common problems in reliably simulating low streamflow and steep recessions (e.g., Pushpalatha et al., 2011; Staudinger et al., 2011), but indicate that reliability of model results is satisfactory for drought analysis based on the threshold level approach. Furthermore, the WATCH Forcing Data (Sect. 3.2), which were used as input, agree rather well with independent data, e.g., FLUXNET (Weedon et al., 2011), although drought characteristics for the arid and polar climates (B- and E-climates) realizations would probably have been more robust if longer time series could have been used. The nine soil and groundwater system realizations cover a wide range of physical catchment structures across the world. The SIs for realizations with the quickly responding groundwater system, which generates more flashy hydrographs, illustrate that even under these conditions the responsiveness of the groundwater system is important relative to climate. Sensitivity analyses showed that the impact of land use (implicitly also soil) and parameterization of snow accumulation and melt (Sect. 3.3) on the SI of climate, soil and groundwater system realizations is limited, implying that the outcome of our study is rather robust.

\subsection{Importance of groundwater}

The groundwater system was demonstrated to be as important as climate control for the development of hydrological drought, and selected soils under grassland seem to be of less importance. A proper assessment of hydrological drought requires adequate simulation of groundwater responsiveness. Most hydrological models that operate at the river basin scale have the potential to sufficiently model the groundwater system for drought studies (e.g., Van Lanen et al., 2004b; Tallaksen et al., 2009; Van Loon et al., 2011). However, recent low flow and hydrological drought studies at the continental scale that analyze the outcome of large-scale models (e.g., Stahl et al., 2011; Prudhomme et al., 2011; Gudmundsson et al., 2012) reveal that these models tend to over- or underestimate river flow variability and perform less well for the lower flows. This suggests that storage processes (e.g., Van Loon et al., 2012), in particular the groundwater system, might not be well described yet. This lack of groundwater representation in large-scale models could also be the reason that a set of eight large-scale models produces a large spread in predicted trends in monthly river flow over the second part of the last century (Stahl et al., 2012). The importance of groundwater for large-scale studies is also of significance through its influence on soil moisture and evapotranspiration, as reported by several authors (e.g., Bierkens and Van den Hurk, 2007; Anyah et al., 2008; Goderniaux et al., 2009; Fan and Miguez-Macho, 2010). However, progress has been restricted because the current generation of large-scale models has grid cells with a resolution of $25-50 \mathrm{~km}$. The potential to improve the representation of the groundwater system in large-scale models will largely increase when future models are able to reach spatial resolutions down to $1 \mathrm{~km}$, as suggested by Wood et al. (2010). At this scale, variation in more local hydrogeological conditions and lateral flow can be included, although model parameterization will remain a challenge (e.g., Sutanudjaja et al., 2011).

\section{Conclusions}

The impact of climate and physical catchment structure on hydrological drought characteristics has been investigated through a controlled modeling experiment that identified drought in simulated daily discharge in a representative number of grid cells across the world over the second part of the 20th century. This has been done for nine soil and groundwater system realizations. The drought analysis approach that was adopted identified drought in discharge as an anomaly from a site-specific, monthly variable threshold, which implies that drought occurs everywhere under all environmental conditions. Summary statistics and a similarity index (SI) were used to investigate the relative importance of climate, soil and groundwater systems. The SI is a comprehensive measure that compares the overlap of the $90 \%$ bivariate probability density fields of drought duration and standardized deficit volume (90\% DD-SDV probability field) of two climate, soil and groundwater system realizations. It provides the level of agreement of two realizations with respect to drought characteristics (high SI implies highly comparable impact of two realizations on hydrological drought characteristics, and low SI the opposite).

SIs for the Köppen-Geiger climate types are about $50 \%$ or more (and in most cases more than $75 \%$ ), meaning that 
a large number of drought events have similar combinations of duration and standardized deficit volume, irrespective of climate type. $90 \%$ DD-SDV probability fields of the equatorial climate (type A) and the temperate climate (type C) have most in common, mutually, and with the other three major climates, which give rise to rather high SIs. Some droughts of the snow climate (type D) last longer and build up a larger deficit than those of the A- and C-climates. Part of the hydrological characteristics of drought events in the arid and polar climates (types B and E) clearly deviate from the three other climates due to larger interannual climate variability.

The selected moderately thick soils under grassland in this study were found to have little effect on drought characteristics, in contrast to groundwater systems. SIs of realizations where only soils have been varied confirm these findings. Median SIs for the soils are higher than $90 \%$, irrespective of climate, and usually above $95 \%$, meaning that the $90 \%$ DD-SDV probability fields barely differ. The responsiveness of groundwater systems to groundwater recharge has strong control on the development of hydrological drought. Slowly responding groundwater systems have clearly fewer drought events than quickly responding systems, but they last longer. The major impact of groundwater systems on the development of hydrological drought is also illustrated by the median SIs that are lower than $60 \%$ for almost all climate conditions. In many realizations, SIs for groundwater systems are lower than, or as low as, the lowest SI for all climate types.

The groundwater system was demonstrated to be as important as climate control for the development of hydrological drought. A proper assessment of hydrological drought includes more than an evaluation of meteorological drought (e.g., through the standard precipitation index). This assessment is essential for appropriate water resources management and planning, meaning that models that are used for drought forecasting and prediction should adequately simulate groundwater responsiveness. Most river basin models have the potential to sufficiently model the groundwater system for drought studies, but the subsurface module (groundwater part) of large-scale models needs improvement. A better representation of the subsurface in large-scale models would help to better understand historic global and continental drought and, hence, to better predict large-scale drought in response to global change.

Acknowledgements. This research was undertaken as part of the European Union (FP6) funded Integrated Project Water and Global Change (WATCH, contract 036946) and contributes to EU FP7 Collaborative project DROUGHT-R\&SPI (grant 282769). One of the authors is supported by NWO (NWO GO-AO/30). The authors thank Paul Torfs (Wageningen University) for his support with writing up the mathematical equations. The research is part of the programme of the Wageningen Institute for Environment and Climate Research (WIMEK-SENSE), and it supports the work of the UNESCO-IHP VII FRIEND programme.

Edited by: F. Pappenberger

\section{Appendix A}

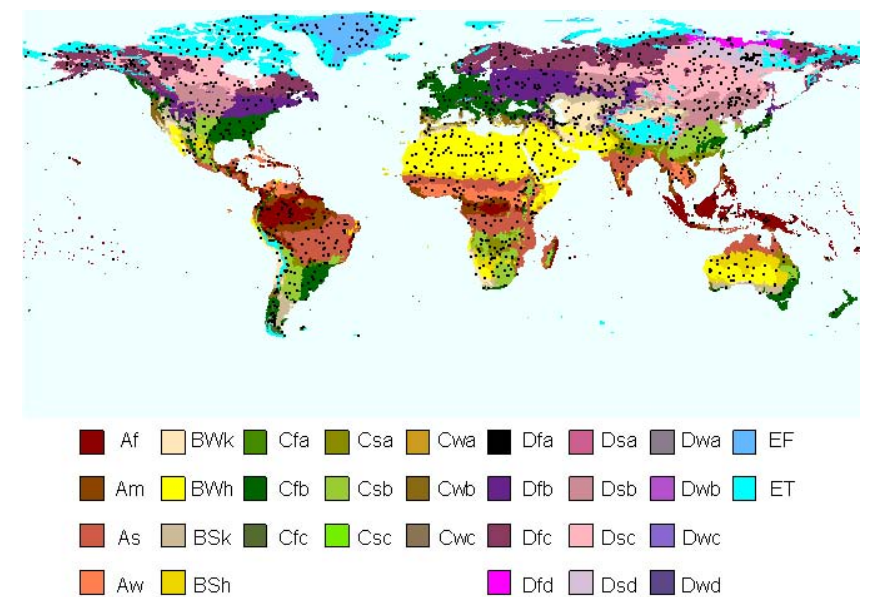

Fig. A1. Global map of Köppen-Geiger climate types derived from the WATCH Forcing Data set over the period 1958-2001 by Wanders et al. (2010). Black dots indicate a total of 1495 locations used in this study.

\section{References}

Allen, R. G., Pereira, L. S., Raes, D., and Smith, M.: Crop Evapotranspiration: Guidelines for Computing Crop Water Requirements, FAO Irrig. Drain. paper 56, Rome, 1988.

Anyah, R. O., Weaver, C. P., Miguez-Macho, G, Fan, Y., and Robock, A.: Incorporating water table dynamics in climate modeling: 3. simulated groundwater influence on coupled land-atmosphere variability, J. Geophys. Res., 113, D07103, doi:10.1029/2007JD009087, 2008.

Andreadis, K., Clark, E., Wood, A., Hamlet, A., and Lettenmaier, D.: Twentieth-century drought in the conterminous United States, J. Hydrometeorol., 6, 985-1001, 2005.

Ashkar, F., Jabi, N. E. I., and Issa, M.: A bivariate analysis of the volume and duration of low-flow events, Stoch. Hydrol. Hydraul., 12, 97-116, 1998.

Bates, B., Kundzewicz, Z., Wu, S., and Palutikof, J.: Climate Change and Water. Technical Paper of the Intergovernmental Panel on Climate Change, Intergovernmental Panel on Climate Change, Geneva, 2008.

Beven, K.: Towards integrated environmental models of everywhere: uncertainty, data and modelling as a learning process, Hydrol. Earth Syst. Sci., 11, 460-467, doi:10.5194/hess-11-4602007, 2007.

Bergström, S.: Development and application of a conceptual runoff model for Scandinavian catchments, SMHI RHO 7, 134 pp., Norrköping, 1976.

Bierkens, M. F. P. and Van den Hurk, B. J. J. M.: Groundwater convergence as a possible mechanism for multi-year persistence in rainfall, Geophys. Res. Lett., 34, L02402, doi:10.1029/2006GL028396, 2007.

Birtles, A. B. and Wilkinson, W. B.: Mathematical simulation of groundwater abstraction from confined aquifers for river 
regulation, Water Resour. Res., 11, 571-580, 1975.

Bouma, J., Droogers, P., Sonneveld, M. P. W., Ritzema, C. J., Hunink, J. E., Immerzeel, W. W., and Kauffman, S.: Hydropedological insights when considering catchment classification, Hydrol. Earth Syst. Sci., 15, 1909-1919, doi:10.5194/hess-15-19092011, 2011.

Bronswijk, J. J. B.: Modelling of water balance, cracking and subsidence of clay soils, J. Hydrol., 97, 199-212, 1988.

Casado Sáenz, M., Montoya, F. F., and Gil de Mingo, R.: The role of groundwater during drought, in coping with drought risk in agriculture and water supply systems, edited by: Iglesias, A., Garrote, L., Cancelliere, A., Cubillo, F., and Wilhite, D. A., Springer, Adv. Nat. Technol. Haz., 26, 221-241, doi:10.1007/978-1-40209045-5, 2009.

Changnon Jr., S. A.: Detecting Drought Conditions in Illinois, Illinois State Water Survey Champaign, Circular 169, 1987.

Corzo Perez, G. A., van Huijgevoort, M. H. J., Voß, F., and van Lanen, H. A. J.: On the spatio-temporal analysis of hydrological droughts from global hydrological models, Hydrol. Earth Syst. Sci., 15, 2963-2978, doi:10.5194/hess-15-2963-2011, 2011.

Dai, A.: Drought under global warming: a review, advanced review, Clim. Change, 2, 45-65, doi:10.1002/wcc.81, 2011.

Dai, A.: Increasing drought under global warming in observations and models, Nat. Clim. Change, 3, 52-58, doi:10.1038/nclimate1633, 2013.

Döll, P., Kaspar, F., and Lehner, B.: A global hydrological model for deriving water availability indicators: model tuning and validation, J. Hydrol., 270, 105-134, 2003.

EEA: Mapping the impacts of natural hazards and technological accidents in Europe. An overview of the last decade, EEA Technical report No 13/2010, Copenhagen, 2010.

Engeland, K. and Hisdal H.: A comparison of low flow estimates in ungauged catchments using regional regression and the HBVmodel, Int. Ser. Prog. Wat. Res., 23, 2567-2586, 2009.

Falkenmark, M., Rockström, J., and Karlberg L.: Present and future water requirements for feeding humanity, Food Sec., 1, 59-69, 2009

Fan, Y. and Miguez-Macho, G.: Potential groundwater contribution to Amazon evapotranspiration, Hydrol. Earth Syst. Sci., 14, 2039-2056, doi:10.5194/hess-14-2039-2010, 2010.

Fleig, A. K., Tallaksen, L. M., Hisdal, H., and Demuth, S.: A global evaluation of streamflow drought characteristics, Hydrol. Earth Syst. Sci., 10, 535-552, doi:10.5194/hess-10-535-2006, 2006.

Gerten, D., Heinke, J., Hoff, H., Biemans, H., Fader, M., and Waha, K.: Global water availability and requirements for future food production, J. Hydrometeorol., 12, 885-899, doi:10.1175/2011JHM1328.1, 2011.

Goderniaux, P., Brouyère, S., Fowler, H. J., Blenkinsop, S., Therrien, R., Orban, P., and Dassargues, A.: Large scale surface - subsurface hydrological model to assess climate change impacts on groundwater reserves, J. Hydrol., 373, 122-138, doi:10.1016/j.jhydrol.2009.04.017, 2009.

Gudmundsson, L., Tallaksen, L. M., Stahl, K., and Fleig, A. K.: Low-frequency variability of European runoff, Hydrol. Earth Syst. Sci., 15, 2853-2869, doi:10.5194/hess-15-2853-2011, 2011.

Gudmundsson, L., Tallaksen, L. M., Stahl, S., Clark, D., Hagemann, S., Bertrand, N., Gerten, D., Hanasaki, N., Heinke, J., Voß, F., and Koirala, S.: Comparing large-scale hydrological models to observed runoff percentiles in Europe, J. Hydrometeorol., 13, 604-620, doi:10.1175/JHM-D-11-083.1, 2012.

Haddeland, I., Clark, D., Franssen, W., Ludwig, F., Voss, F., Arnell, N., Bertrand, N., Best, M., Folwell, S., Gerten, D., Gomes, S., Gosling, S. N., Hagemann, S., Hanasaki, N., Harding, R., Heinke, J., Kabat, P., Koirala, S., Oki, T., Polcher, J., Stacke, T., Viterbo, P., Weedon, G. P., and Yeh, P.: Multi-model estimate of the global water balance: setup and first results, J. Hydrometeorol., 12, 869-884, doi:10.1175/2011JHM1324.1, 2011.

Hannaford, J., Lloyd-Hughes, B., Keef, C., Parry, S., and Prudhomme, C.: Examining the large-scale spatial coherence of European drought using regional indicators of precipitation and streamflow deficit, Hydrol. Process., 25, 1146-1162, 2010.

Hannaford, J., Buys, G., Stahl, K., and Tallaksen, L. M.: The influence of decadal-scale variability on trends in long European streamflow records, Hydrol. Earth Syst. Sci. Discuss., 10, 1859 1896, doi:10.5194/hessd-10-1859-2013, 2013.

Hannah, D. M., Demuth, S., Van Lanen, H. A. J., Looser, U., Prudhomme, C., Rees, R., Stahl, K., and Tallaksen, L. M.: Large-scale river flow archives: importance, current status and future needs, Hydrol. Process., 25, 1191-1200, 2010.

Hisdal, H., Stahl, K., Tallaksen, L. M., and Demuth, S.: Have streamflow droughts in Europe become more severe or frequent?, Int. J. Climatol., 21, 317-333, 2001.

Hisdal, H., Tallaksen, L. M., Clausen, B., Peters, E., and Gustard, A.: Hydrological drought characteristics, in: Hydrological drought processes and estimation methods for streamflow and groundwater, edited by: Tallaksen, L. M. and Van Lanen, H. A. J., Dev. Water Sci., 48, 139-198, 2004.

ISDR: Global assessment report on disaster risk reduction. risk and poverty in a changing climate - invest today for a safer tomorrow, United Nations, Geneva, 2009.

Kim, T.-W., Valde's, J. B., and Yoo, C.: Nonparametric approach for estimating return periods of droughts in arid regions, J. Hydrol. Eng., 8, 237-246, 2003.

Kottek, M., Grieser, J., Beck, C., Rudolf, B., and Rubel, F.: World Map of the Köppen-Geiger climate classification updated, Meteorol. Z., 15, 259-263, doi:10.1127/0941-2948/2006/0130, 2006.

Kraijenhof van de Leur, D. A.: Some effects of the unsaturated zone on nonsteady free-surface groundwater flow as studied in a sealed granular model, J. Geophys. Res., 67, 4347-4362, 1962.

Laizé, C. R. L. and Hannah, D. M.: Modification of climate-river flow associations by basin properties, J. Hydrol., 389, 186-204, 2010.

Leblanc, M. J., Tregoning, P., Ramillien, G., Tweed, S. O., and Fakes, A.: Basin-scale, integrated observations of the early $21 \mathrm{st}$ century multiyear drought in southeast Australia, Water Resour. Res., 45, W04408, doi:10.1029/2008WR007333, 2009.

Lewis, S. L., Brando, P. M., Phillips, O. L., Van der Heijden, G. M. F., and Nepstad, D.: The 2010 Amazon Drought, Science, 331, p. 554, 2011.

Masih, I., Uhlenbrook, S., Maskey, S., and Ahmad, M. D.: Regionalization of a conceptual rainfall-runoff model based on similarity of the flow duration curve: a case study from the semi-arid Karkheh basin, Iran, J. Hydrol. 391, 188-201, 2010.

Melsen, L. A., Van Lanen, H. A. J., Wanders, N., Van Huijgevoort, M. H. J., and Weedon, G. P.: Reference evapotranspiration with radiation-based and temperature-based method - impact on hydrological drought using WATCH 
Forcing Data, WATCH Technical Report No. 39, available at: www.eu-watch.org/publications/technical-reports (last access: 1 September 2012), 2011.

Mishra, K. K. and Singh, V. P.: A review of drought concepts, J. Hydrol., 391, 202-216, 2010.

Mitchell, T. D. and Jones, P. D.: An improved method of constructing a database of monthly climate observations and associated high-resolution grids, Int. J. Climatol., 25, 693-712, 2005.

Peel, M. C., McMahon, T. A., and Pegram, G. S.: Global analysis of runs of annual precipitation and runoff equal to or below the median: run magnitude and severity, Int. J. Climatol., 25, 549568, 2005.

Peel, M. C., Finlayson, B. L., and McMahon, T. A.: Updated world map of the Köppen-Geiger climate classification, Hydrol. Earth Syst. Sci., 11, 1633-1644, doi:10.5194/hess-11-16332007, 2007.

Peters, E.: Propagation of drought through groundwater systems. Illustrated in the Pang (UK) and Upper-Guadiana (ES) catchments, $\mathrm{PhD}$ thesis, Wageningen University, The Netherlands, 2003.

Peters, E., Torfs, P. J. J. F., Van Lanen, H. A. J., and Bier, G.: Propagation of drought through groundwater - a new approach using linear reservoir theory, Hydrol. Process., 17 3023-3040, 2003.

Peters, E., Bier, G., Van Lanen, H. A. J., and Torfs, P. J. J. F.: Propagation and spatial distribution of drought in a groundwater catchment, J. Hydrol., 321, 257-275, 2006.

Prudhomme, C., Parry, S., Hannaford, J., Clark, D. B., Hagemann, S., and Voss, F.: How well do large-scale models reproduce regional hydrological extremes in Europe?, J. Hydrometeorol., 12, 1181-1204, doi:10.1175/2011JHM1387.1, 2011.

Pushpalatha, R., Perrin, C., Moine, N. L., Mathevet, T., and Andréassian, V.: A downward structural sensitivity analysis of hydrological models to improve low-flow simulation, J. Hydrol., 411, 66-76, doi:10.1016/j.jhydrol.2011.09.034, 2011.

Ritzema, H. P. (Ed.): Subsurface flow to drains, In: Drainage Principles and Applications, 2nd Edn., International Institute for Land Reclamation and Improvement, Wageningen, 263-303, 1994.

Schneider, U., Becker, A., Meyer-Christoffer, A., Ziese, M., and Rudolf, B.: Global Precipitation Analysis Products of the GPCC. Global Precipitation Climatology Centre (GPCC), Deutscher Wetterdienst, Offenbach a. M., Germany, available at: ftp://ftp-anon.dwd.de/pub/data/gpcc/PDF/GPCC_intro_ products_2008.pdf (last access: 24 October 2012), 2011.

Seibert, J.: Multi-criteria calibration of a conceptual runoff model using a genetic algorithm, Hydrol. Earth Syst. Sci., 4, 215-224, doi:10.5194/hess-4-215-2000, 2000.

Seibert, J.: HBV light version 2, user's manual, available at: http: //people.su.se/ jseib/HBV/HBV_manual_2005.pdf (last access: 25 October 2012), 2005.

Seibert, J., Uhlenbrook, S., Leibundgut, C., and Halldin, S.: Multiscale calibration and validation of a conceptual rainfall-runoff model, Phys. Chem. Earth B, 25, 59-64, 2000.

Seneviratne, S. I., Nicholls, N., Easterling, D., Goodess, C. M., Kanae, S., Kossin, J., Luo, Y., Marengo, J., McInnes, K., Rahimi, M., Reichstein, M., Sorteberg, A., Vera, C., and Zhang, X.: Changes in climate extremes and their impacts on the natural physical environment, in: Managing the Risks of Extreme Events and Disasters to Advance Climate Change Adaptation, edited by: Field, C. B., Barros, V., Stocker, T. F., Qin, D., Dokken, D. J., Ebi, K. L., Mastrandrea, M. D., Mach, K. J., Plattner, G.-K.,
Allen, S. K., Tignor, M., and Midgley, P. M., A Special Report of Working Groups I and II of the Intergovernmental Panel on Climate Change (IPCC), Cambridge University Press, Cambridge, UK, and New York, NY, USA, 109-230, 2012.

Sheffield, J. and Wood, E. F.: Global trends and variability in soil moisture and drought characteristics, 1950-2000, from observation-driven simulations of the terrestrial hydrologic cycle, J. Climate, 21, 432-458, 2008a.

Sheffield, J. and Wood, E. F.: Projected changes in drought occurrence under future global warming from multi-model, multiscenario, IPCC AR4 simulations, Clim. Dynam., 31, 79-105, 2008 b.

Sheffield, J., Andreadis, K., Wood, E. F., and Lettenmaier, D.: Global and continental drought in the second half of the twentieth century: severity-area-duration analysis and temporal variability of large-scale events, J. Climate, 22, 1962-1981, 2009.

Sheffield, J., Wood, E. F., and Roderick, M. L.: Little change in global drought over the past 60 years. Nature, 491, 435-438, doi:10.1038/nature11575, 2012.

Shukla, S. and Wood, A.: Use of a standardized runoff index for characterizing hydrologic drought, Geophys. Res. Lett., 35, L02405, doi:10.1029/2007GL032487, 2008.

Smakhtin, V. U.: Low flow hydrology: a review, J. Hydrol., 240, 147-186, 2001.

Stahl, K. and Hisdal, H.: Hydroclimatology, in: Hydrological Drought, Processes and Estimation Methods for Streamflow and Groundwater, Chapter 2, edited by: Tallaksen, L. M. and Van Lanen, H. A. J., Dev. Water Sci., 48, Amsterdam, 19-51, 2004.

Stahl, K., Hisdal, H., Hannaford, J., Tallaksen, L. M., van Lanen, H. A. J., Sauquet, E., Demuth, S., Fendekova, M., and Jódar, J.: Streamflow trends in Europe: evidence from a dataset of near-natural catchments, Hydrol. Earth Syst. Sci., 14, 23672382, doi:10.5194/hess-14-2367-2010, 2010.

Stahl, K., Tallaksen, L. M., Gudmundsson, L., and Christensen, J. H.: Streamflow data from small basins: a challenging test to high resolution regional climate modelling, J. Hydrometeorol., 12, 900-912, doi:10.1175/2011JHM1356.1, 2011.

Stahl, K., Tallaksen, L. M., Hannaford, J., and van Lanen, H. A. J.: Filling the white space on maps of European runoff trends: estimates from a multi-model ensemble, Hydrol. Earth Syst. Sci., 16, 2035-2047, doi:10.5194/hess-16-2035-2012, 2012.

Staudinger, M., Stahl, K., Seibert, J., Clark, M. P., and Tallaksen, L. M.: Comparison of hydrological model structures based on recession and low flow simulations, Hydrol. Earth Syst. Sci., 15, 3447-3459, doi:10.5194/hess-15-3447-2011, 2011.

Sutanudjaja, E. H., van Beek, L. P. H., de Jong, S. M., van Geer, F. C., and Bierkens, M. F. P.: Large-scale groundwater modeling using global datasets: a test case for the Rhine-Meuse basin, Hydrol. Earth Syst. Sci., 15, 2913-2935, doi:10.5194/hess-15-2913-2011, 2011.

Tague, C., Grant, G., Farrell, M., Choate, J., and Jefferson, A.: Deep groundwater mediates streamflow response to climate warming in the Oregon Cascades, Clim. Change, 86, 189-210, doi:10.1007/s10584-007-9294-8, 2008.

Tallaksen, L. M. and van Lanen, H. A. J. (Eds.): Hydrological Drought. Processes and Estimation Methods for Streamflow and Groundwater, Developments in Water Science, 48, Elsevier Science B.V., Amsterdam, p. 579, 2004. 
Tallaksen, L. M., Madsen, H., and Clausen, B.: On the definition and modelling of streamflow drought duration and deficit volume, Hydrol. Sci. J., 42, 15-33, 1997.

Tallaksen, L. M., Hisdal, H., and Van Lanen, H. A. J.: Space-time modeling of catchment scale drought characteristics, J. Hydrol., 375, 363-372, doi:10.1016/j.jhydrol.2009.06.032, 2009.

Tijdeman, E., Van Loon, A. F., Wanders, N., and Van Lanen, H. A. J.: The effect of climate on droughts and their propagation in different parts of the hydrological cycle. DROUGHT-R\&SPI Technical Report No. 2, available at: http://www.eu-drought.org/ technicalreports (last access: 21 March 2013), 2012.

UN: Humanitarian Requirements for the Horn of Africa Drought 2011. United Nations Report. Office for the Coordination of Humanitarian Affairs (OCHA), New York and Geneva, available at: http://reliefweb.int/sites/reliefweb.int/files/ resources/Full_report_216.pdf, 2011.

Uppala, S. M., Kallberg, P. W., Simmons, A. J., Andrae, U., Bechtold, V. D., Fiorino, M., Gibson, J. K., Haseler, J., Hernandez, A., Kelly, G. A., Li, X., Onogi, K., Saarinen, S., Sokka, N., Allan, R. P., Andersson, E., Arpe, K., Balmaseda, M. A., Beljaars, A. C. M., Van de Berg, L., Bidlot, J., Bormann, N., Caires, S., Chevallier, F., Dethof, A., Dragosavac, M., Fisher, M, Fuentes, M., Hagemann, S., Holm, E., Hoskins, B. J., Isaksen, L., Janssen, P., Jenne, R., Mcnally, A. P., Mahfouf, J. F., Morcrette, J. J., Rayner, N. A., Saunders, R. W., Simon, P., Sterl, A, Trenberth, K. E., Untch, A., Vasiljevic, D., Viterbo, P., and Woollen, J.: The ERA-40 re-analysis, Q. J. Roy. Meteor. Soc., 131, 2961-3012, 2005.

Van der Knijff, J. and De Roo, A.: LISFLOOD: Distributed Water Balance and Flood Simulation Model, Revised User Manual, JRC Scientific and Technical Reports EUR 22166 EN/2, Ispra, 2008.

Van Huijgevoort, M. H. J., Van Loon, A. F., Rakovec, O., Haddeland, I., Horáček, S., and Van Lanen, H. A. J.: Drought assessment using local and large-scale forcing data in small catchments, in: Global Change: Facing Risks and Threats to Water Resources, edited by: Servat, E., Demuth, S., Dezetter, A., Daniell, T., Ferrari, E., Ijjaali, M., Jabrane, R., Van Lanen, H., and Huang, Y., IAHS Publ. No. 340, 77-85, 2010.

Van Huijgevoort, M. H. J., Hazenberg, P., van Lanen, H. A. J., and Uijlenhoet, R.: A generic method for hydrological drought identification across different climate regions, Hydrol. Earth Syst. Sci., 16, 2437-2451, doi:10.5194/hess-16-2437-2012, 2012.

Van Lanen, H. A. J. and Tallaksen, L. M.: Hydrological drought, climate variability and change, in: Climate and Water, edited by: Heinonen, M., Proceedings of the third International Conference on Climate and Water, Helsinki, 3-6 September 2007, 488-493, 2007.

Van Lanen, H. A. J. and Tallaksen, L. M.: Drought in Europe, in: Proceedings Water Down Under, edited by: Lambert, M., Daniell, T., and Leonard, M., Adelaide, 14-17 April 2008, 98108, 2008.

Van Lanen, H. A. J., Weerts, A. H., Kroon, T., and Dijksma, R.: Estimation of groundwater recharge in areas with deep groundwater tables using transient groundwater flow modelling, Proceedings International Confereince on "Calibration and Reliability of Groundwater Modelling”, September 1999, Golden, USA, 307316, 1996.
Van Lanen, H. A. J., Fendeková, M., Kupczyk, E., Kasprzyk, A., and Pokojski, W.: Flow Generating Processes, in: Hydrological Drought, Processes and Estimation Methods for Streamflow and Groundwater, Chapter 3, edited by: Tallaksen, L. M. and Van Lanen, H. A. J., Dev. Water Sci., 48, Amsterdam, 53-96, 2004a.

Van Lanen, H. A. J., Kašpárek, L., Novický, O., Querner, E. P., Fendeková M., and Kupczyk, E.: Human Influences, in: Hydrological Drought, Processes and Estimation Methods for Streamflow and Groundwater, Chapter 9, edited by: Tallaksen, L. M. and Van Lanen, H. A. J., Dev. Water Sci., 48, Amsterdam, 347-410, 2004 b.

Van Loon, A. F. and Van Lanen, H. A. J.: A process-based typology of hydrological drought, Hydrol. Earth Syst. Sci., 16, 19151946, doi:10.5194/hess-16-1915-2012, 2012.

Van Loon, A. F., Van Lanen, H. A. J., Hisdal, H., Tallaksen, L. M., Fendeková, M., Oosterwijk, J., Horvát, O., and Machlica, A.: Understanding hydrological winter drought in Europe, in: Global Change: Facing Risks and Threats to Water Resources, edited by: Servat, E., Demuth, S., Dezetter, A., Daniell, T., Ferrari, E., Ijjaali, M., Jabrane, R., Van Lanen, H., and Huang Y., IAHS Publ., 340, 189-197, 2010.

Van Loon, A. F., Van Lanen, H. A. J., Tallaksen, L. M., Hanel, M., Fendeková, M., Machlica M, Sapriza, G., Koutroulis, A., Van Huijgevoort, M. H. J., Jódar Bermúdez, J., Hisdal, H., and Tsanis, I.: Propagation of drought through the hydrological cycle, WATCH Technical Report No. 32, available at: www.eu-watch. org/publications/technical-reports (last access: 1 October 2011), 2011.

Van Loon, A. F., Van Huijgevoort, M. H. J., and Van Lanen, H. A. J.: Evaluation of drought propagation in an ensemble mean of large-scale hydrological models, Hydrol. Earth Syst. Sci., 16, 4057-4078, doi:10.5194/hess-16-4057-2012, 2012.

Van Stiphout, T. P. J., Van Lanen, H. A. J., Boersma, O. H., and Bouma, J.: The effect of bypass flow and internal catchment of rain on the water regime in a clay loam grassland soil, J. Hydrol., 95, 1-11, 1987.

Vidal, J.-P., Martin, E., Franchistéguy, L., Habets, F., Soubeyroux, J.-M., Blanchard, M., and Baillon, M.: Multilevel and multiscale drought reanalysis over France with the Safran-IsbaModcou hydrometeorological suite, Hydrol. Earth Syst. Sci., 14, 459-478, doi:10.5194/hess-14-459-2010, 2010.

Wand, M. P.: Fast computation of multivariate kernel estimators, J. Comput. Graph. Stat., 3, 433-445, 1994.

Wand, M. P. and Jones, M. C.: Kernel Smoothing, Chapman and Hall, London, 1995.

Wanders, N., Van Lanen, H. A. J., and Van Loon, A. F.: Indicators for drought characterization on a global scale, WATCH Technical Report No. 24, available at: www.eu-watch.org/publications/ technical-reports (last access: 1 October 2011), 2010.

Weedon, G. P., Gomes, S., Viterbo, P., Shuttleworth, W. J., Blyth, E., Österle, H., Adam, J. C., Bellouin, N., Boucher, O., and Best, M.: Creation of the WATCH forcing data and its use to assess global and regional reference crop evaporation over land during the twentieth century, J. Hydrometeorol., 12, 823-848, doi:10.1175/2011JHM1369.1, 2011.

Wehner, M., Easterling, D. R., Lawrimore, J. H., Heim Jr., R. R., Vose, R. S.,and Santer, B. D.: Projections of future drought in the continental United States and Mexico, J. Hydrometeorol., 12, 823-848, doi:10.1175/2011JHM1351.1, 2011. 
Widén-Nilsson, E., Halldin, S., and Xu, C.-Y.: Global waterbalance modelling with WASMOD-M: parameter estimation and regionalisation, J. Hydrol., 340, 105-118, doi:10.1016/j.jhydrol.2007.04.002, 2007.

Wilhite, D. A.: Drought: A Global Assessment, Routledge, London, New York, 2000.

Wilson, D., Hisdal, H., and Lawrence, D.: Has streamflow changed in the nordic countries? - Recent trends, J. Hydrol., 394, 334346, doi:10.1016/j.jhydrol.2010.09.010, 2010.

Wong, K. W., Beldring, S., Engen-Skaugen, T., Haddeland, I., and Hisdal, H.: Climate change effects on spatiotemporal patterns of hydroclimatological summer droughts in Norway, J. Hydrometeorol., 12, 1205-1220, doi:10.1175/2011JHM1357.1, 2011.

Wood, E. F., Roundy, J. K., Troy, T. J., Van Beek, L. P. H., Bierkens, M. F. P., Blyth, E., De Roo, A., Döll, P., Ek, M., Famiglietti, J., Gochis, D., Van de Giesen, N., Houser, P., Jaffe, P., Kollet, S., Lehner, B., Lettenmaier, D. P., PetersLidard, C., Sivapalan, M., Sheffield, J., Wade, A., and Whitehead, P.: Hyper-resolution global land surface modeling: meeting a grand challenge for monitoring Earth's terrestrial water, Water Resour. Res., 47, W05301, doi:10.1029/2010WR010090, 2011.
Wösten, J. H. M., Veerman, G. J., De Groot, W. J. M., and Stolte, J.: Waterretentie, - en doorlatendheidskarakteristieken van boven, en ondergronden in Nederland: de Staringreeks. Technisch Rapport 153, Alterra, Wageningen, available at: www2.alterra.wur. nl/Webdocs/PDFFiles/Alterrarapporten/AlterraRapport153.pdf (last access: 1 October 2011), 2001a.

Wösten, J. H. M., Pachepsky, Y. A., and Rawls, W. J.: Pedotranfer functions: bridging the gap between available basic soil data and missing soil hydraulic characteristics, J. Hydrol., 251, 123-150, 2001b.

WWDR: World Water Assessment Programme 2009, The United Nations World Water Development Report 3: Water in a Changing World, UNESCO, Paris and Earthscan, London, 2009.

Yevjevich, V.: An objective approach to definition and investigations of continental hydrologic droughts, Hydrology Papers 23, Colorado State University, Fort Collins, USA, 1967.

Zelenhasic, E. and Salvai, A.: A method of streamflow drought analysis, Water Resour. Res., 23, 156-168, 1987. 